This article was downloaded by: [Carnegie Mellon University]

On: 02 February 2015, At: 21:32

Publisher: Routledge

Informa Ltd Registered in England and Wales Registered Number: 1072954 Registered office: Mortimer House, 37-41 Mortimer Street, London W1T 3J H, UK

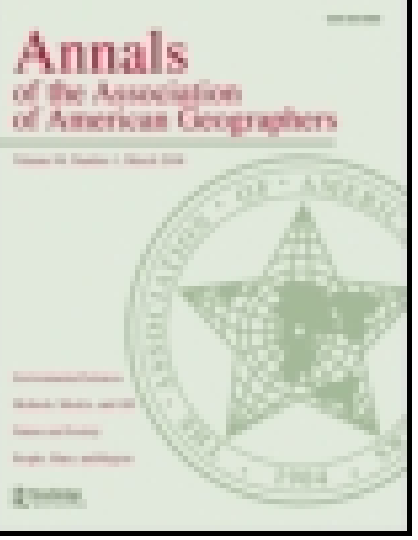

\title{
Annals of the Association of American Geographers
}

Publication details, including instructions for authors and subscription information:

http:// www.tandfonline.com/loi/ raag20

\section{THE COLORODO FRONT RANGE: A STUDY IN PHYSIOGRAPHIC PRESENTATION}

W. M. Davis

Published online: 18 Feb 2009.

To cite this article: W. M. Davis (1911) THE COLORODO FRONT RANGE: A STUDY IN PHYSIOGRAPHIC PRESENTATION, Annals of the Association of American Geographers, 1:1, 21-83, DOI:

$\underline{10.1080 / 00045601109357005}$

To link to this article: http:// dx.doi.org/ 10.1080/00045601109357005

\section{PLEASE SCROLL DOWN FOR ARTICLE}

Taylor \& Francis makes every effort to ensure the accuracy of all the information (the "Content") contained in the publications on our platform. However, Taylor \& Francis, our agents, and our licensors make no representations or warranties whatsoever as to the accuracy, completeness, or suitability for any purpose of the Content. Any opinions and views expressed in this publication are the opinions and views of the authors, and are not the views of or endorsed by Taylor \& Francis. The accuracy of the Content should not be relied upon and should be independently verified with primary sources of information. Taylor and Francis shall not be liable for any losses, actions, claims, proceedings, demands, costs, expenses, damages, and other liabilities whatsoever or howsoever caused arising directly or indirectly in connection with, in relation to or arising out of the use of the Content.

This article may be used for research, teaching, and private study purposes. Any substantial or systematic reproduction, redistribution, reselling, loan, sub-licensing, systematic supply, or distribution in any form to anyone is expressly forbidden. Terms \& Conditions of access and use can be found at http://www.tandfonline.com/page/termsand-conditions 


\section{THE COLORADO FRONT RANGE}

\section{A STUDY IN PHYSIOGRAPHIC PRESENTATION}

W. M. DAVIS

\section{DEDICATED TO THE MEMORY OF ARCHIBALD R. MARVINE}

Born in Auburn, X. Y., Sept. 26, 1848

Graduated at Harrard, M. E., summa cum laude, 1870

Died in Washington, D. C., March 2, 18i6

"The mountain zone lying between the main divide and the Plains.. . a park region of rolling pine-sprinkled surfaces . . . impresses one as being, with a few exceptions, a region of very uniform or gently undulating general elevation, carved by the powers of erosion, perhaps partly glacial but mostly by streams, into a mountain area of which portions are exceedingly rugged."

A. R. Marvine, in Hayden's Report for 1873. Washington, 1874, p. 89.

\section{CONTENTS}

Two visits to the Rocky Mountains................................ 28

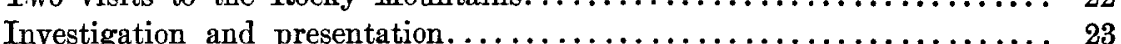

The six chief methods of geographical presentation............. 23

The various treatments, grades, and forms of presentation.......... 24

Explanatory treatment better than empirical................. 25

Brief and medium forms of advanced grade.................. 25

Choice among the six methods of presentation................. 25

Relation of explanatory regional presentation to analysis and system..... 29

Structure, process and stage........................... 30

The Front Range of the Rocky Mountains in central Colorado; conidensed, technical, explanatory, regional presentation.............. 31

Remarks upon condensed technical presentation................. 32

Graphic aid in geographical presentation..................... 33

Condensed technical presentation and condensed diagram of the Front Range...................................... 35

Remarks upon illustrated technical presentation................ 36

Explicit statement of the corollaries implied in a condensed technical statement...................................... 36

Subdivisions of the Front Range....................... 37

The highland peneplain of the Front Range.................40

Highlands and mountains treated as uplifted and dissected peneplains... 44

Two-cycle mountains ................................. 44

Systematic equipment with standardized types for the explanatory description of mountains................................. 47

The monadnocks. ..................................... 48

The valleys. ...................................... 50

Glacial sculpture of the higher mountains and valleys............53 
Domes, cirques, and troughs......................... 57

Cirques and troughs at the head of the Boulder creeks............ 59

The trough of Clear Creek.............................. 62

The mountain border................................. 64

Marvine's early work on the Front Range................. 66

The problem of intersecting peneplains. ................... 69

The need of systematic preparation for regional work............ 70

References.......................................... $7_{2}$

Two Visits to The Rocky Mountains.-In the summer of 1869, Professor J. D. Whitney visited the Rocky Mountains of Colorado with a small party, including four of his students in the Mining School at Harvard. His object was chiefly to determine the altitude of the loftiest ranges that he could reach, regarding which a brief report was published in Petermann's Mitteilungen (1871). The highest summit that he found was in the Sawatch Range west of the upper Arkansas Valley, and was named Mt. Harvard (14,375 feet) after the university in which he was then teaching; while the next highest summit immediately to the south in the same range was named Mt. Yale (14,187 feet) after the university from which he had graduated thirty years before. The name Mt. Princeton (14,196 feet) was given, a few years later, to the fine mass next south of Mt. Yale. Mts. Elbert (14,421 feet) and Massive (14,424 feet), farther north in the same range, have been found by later surveys to have greater height.

The four students in Whitney's party were:-Archibald R. Marvine who, after finishing his studies in 1870, joined the Wheeler Survey and later the Hayden Survey, his excellent work being cut short by his death in 1876; Henry Gannett, whose membership in the Hayden Survey has been followed by long and expert service in the United States Geological Surrey; Joseph H. Bridge, who made successful application of his mining studies in the West; and myself who, after a détour into astronomy which took me to South America from 1870 to 1873 , returned to geology and geography at Harvard in 1876.

After having various sights of the Rocky Mountains in 1877, 1883, $1891,1897,1900,1901,1902,1904$, and 1909, some only from passing trains, others more deliberate, I had opportunity of visiting the ranges of Colorado again in the summer of 1910, in company with Professor Mark Jefferson of Ypsilanti, Mich., Professor W. M. Gregory of Cleveland, O., and Professor E. W. Shuler of Fort Worth, Tex., when we carried on the work of a field course in advanced physiography as part of the Harvard Summer School of that year. We spent something more than two weeks together, and my companions remained about three weeks longer, to continue a closer examination of selected 
problems. Our studies made repeated application of the results announced for the Boulder district by Fenneman (1905) and for the Georgetown district by Ball (1908, 31-35).

The contrasts between the visits of 1869 and 1910 were strongly marked in many ways. In 1869 , Cheyenne was the nearest railroad station; we went thence by stage over-night to Denver, a small frontier town, where we outfitted for a camping trip of six weeks in the unsurveyed mountains. In 1910, Denver was a good sized city and an important railroad center, from which we could quickly enter or cross the mountains by train, to the Northwest, West or Southwest, in the most convenient fashion for rapid work. But there was another contrast:-in 1869 the highest geographical ambitions of our party were to determine the latitude, longitude and altitude of the more important mountains, to make hachured sketch maps of the district and to write brief empirical descriptions of the scenery. In 1910 there was no need of surveying, as fairly good governmental maps were available for much of the field; our efforts were therefore directed almost exclusively to the preparation of systematic explanatory descriptions of the mountain landscape, following methods that were unimagined in 1869 .

Investigation and Presentatiox. - When a geographer returns from a field of observation, such as the Rocky Mountains in Colorado, and after a period of studs proposes to present the results of his work at a meeting of his colleagues, his attention passes from the science of geographical investigation to the art of geographical presentation. Through observation and reflection, he has learned the facts of his field and their meaning. It is then his task to arrange a suitable selection of his material in such form and order that the essential features of his problem, upon which he has spent weeks or months, can be acquired by his hearers in half an hour or an hour. The things that he has seen must be presented in Wort und Bild, as the Germans say, so that those who have not visited his field may gain a repaying appreciation of its main features.

The Six Chief Methods of Geographical Presentation.-An inspection of geographical articles in scientific journals discloses six chief methods of presentation, which may be called the narrative, the inductive, the analytic, the historic, the systematic, and the regional. In narrative presentation, the observer recounts the facts that he observed and the thoughts that they suggested, in the order in which they were encountered. In inductive presentation, the observed facts are arranged in some reasonable order, independent of theory as well as of the order of observation and record, so that their leading characteristics may be generalized. In analytical presentation, the best theoretical explanation of the observed facts, as dependent on certain 
unobservable facts and processes of past occurrence, is selected from various proposed explanations, and set forth in such form that the hearers may judge of its sufficiency. In historic presentation, the gradual development of a problem is reviewed by summarizing the successive contributions made to its solution by various investigators. In systematic presentation, typical examples, as acquired by observations, induction, analysis, and history, are arranged in a well considered order, so that they may be easily found when wanted. In regional presentation, the climax of geographical work is reached:-here the attempt is made to describe, in their actual spacial relations, all the geographical features which occur together in a given district; these features having previously become well known by observation and induction, well understood by analysis, well appreciated by historic review, and well arranged in relation to similar features elsewhere by systematic classification.

Evidently enough, the six methods of presentation may be variously combined: evidently also, when an investigation is finished, and the opportunity for presentation approaches, the investigator must choose among the several methods of presentation, and select that one which will best accomplish his object. In this particular instance, the problem is to determine how the results of three weeks' physiographic observation in the Rocky Mountains in the summer of 1910 can be best set before the members of our Association.

The Variods Treatments, Grades, and Forms of PresentaTroN.-All the methods of presentation above noted, except the analytic, may be treated either with the older fashioned empirical motive, or with the newer fashioned explanatory motive; thus eleven varieties of presentation become possible. Each of these eleven varieties may be adapted to different grades of geographical proficiency; for example, to the youthful grade of pupils in secondary schools, or to the higher grade of mature but not proficient hearers, or to the highest grade of proficient experts: thus we have thirty-three varieties of presentation. Furthermore, each of these varieties may be condensed into a brief form, given a medium length, or expanded to a full and detailed statement. Thus there are at least ninety-nine varieties of presentation; and if it be desired to subdivide grades and forms more minutely, the number of varieties might be still farther increased. When so many kinds of presentation are possible, it behooves a geographer to be all the more careful to choose the particular kind that shall best suit his needs. The problem here encountered is a practical one, and one that needs careful consideration. Let us examine briefly the advantages and disadvantages of the various styles of presentation, considering treatment first, then form and grade. 
Explanatory Treatment Better Than Empirical.-In these modern days of an evolutionary philosophy, it is desirable to discard the empirical treatment of geographical problems, and to adopt as far as possible a thorough-going explanatory treatment: not that everything geographical can today be safely explained to the satisfaction of all geographers; but that all geographers are now satisfied that everything geographical has been evolved from past conditions into present conditions by ordinary, orderly processes, and is therefore in its nature susceptible of reasonable explanation, even if the explanation is not yet found; and further that many, though perhaps not yet most, geographers are persuaded that there is no way of describing geographical facts so effectively as by explaining them. A conscious and intentional effort will therefore be made to adopt an explanatory treatment in this essay, that is, to introduce so much of the past history of the facts under consideration as is helpful in describing their present condition. If in some problem where no satisfactory explanation is found, it may be necessary to fall back on empirical statements, this will be done consciously and intentionally, but with expressed discontent, and with a lively hope that the missing explanation may soon be found.

Briff and Medium Forms of Advanced Grade.-If it be appropriate anywhere to apply a terse and technical form of explanatory treatment in the discussion of a physiographical problem, it must be at a meeting of the only geographical society in the world which, as far as $I$ know, requires some expert knowledge of and some creditable performance in geography as a qualification for membership. Hence experiment in that kind of presentation will here be made. It will be followed by a statement in more expanded form, in which the fuller meaning of the terse statement will be explicitly set forth, just as a terse geometrical theorem is often followed by corollaries in which explicit statement is made of various consequences that are implicitly contained in the theorem.

Chorce Among the Six Metrods of Presentation.-The simple experiences of a summer vacation in Colorado hardly deserve narrative presentation at a meeting of the Association of American Geographers. True, it may sometimes be worth while to state concisely the itinerary of a trip, but that is a very dry form of record, quite unlike the lively, story-telling quality of good narrative, and it is not needed here. Furthermore, the disorderly sequence of observations, now on one railroad line, now on another, here strolling over the highlands, there descending the steep sides of a young valley, would produce a very confused impression when set forth in narrative style, and such an impression must be avoided. Even if we had had novel adventures, which was by no means the case, it would not suit the objective purpose of our Association to introduce so much subjec- 
tive matter as narration usually contains; for however well subjective narration may serve to entertain a popular audience, it is poorly fitted for the presentation of the scientific results of a journey, or for the edification of the members of this Association.

Inductive presentation is likewise not appropriate for the present purpose. It is a good method for the presentation of well defined facts to an audience of small experience and of undeveloped critical powers, but it is a poor method of treating novel problems before an audience of experts, because only simple geographical generalizations can be reached by induction alone, and most of these have been reached years ago. Hence, instead of here attempting to re-establish simple generalizations by going over their induction again, they will be treated, in so far as they are here pertinent, as accepted truths. For example, the relation of trunk and branch valleys at their junctions may be established by observations in the Rocky Mountains; but as this important relation has been known with respect to normally eroded valleys for more than a century, and with respect to glacially deepened valleys for more than a decade, it need not be treated today as a novelty that still demands the support of new instances. On the other hand, most of the physiographic problems of the Rocky Mountains are far beyond the reach of inductive solution, because they involve the theoretical discussion of unobservable past facts, as well as of observable present facts. If, in spite of being slow, inductive presentation is prized as being safe, let it be remembered that safety is really a quality of investigation, while the correspondingly admirable quality of presentation is clearness; and inductive presentation is not necessarily clear, indeed, it is not strictly applicable unless the problems dealt with are very simple. It sometimes happens that a would-be cautious investigator presents his conclusions inductively, as if thereby to fortify them; but in such cases deduction often enters as an essential although unintentional and unrecognized supplement to induction; and the unrecognized use of deduction renders would-be inductive presentation turbid. If deduction is to be used at all, let it be used consciously, as it is in the analytical method. Inductive presentation is therefore discarded in this essay, excepting in so far as it enters into other methods of presentation.

The analytical method of attacking various problems was repeatedly employed while our work was going on in the field and afterwards, for this is the only method that is capable of supplying safe explanations for many of the facts we encountered; and inasmuch as our intention of using explanatory treatment has already been avowed, analysis is an essential part of our work. Analysis is, indeed, after observation, the mainstay of the explanatory treatment of geographical problems; and it must always be so, as long as the problems involve 
the understanding of unseen facts in past time as the explanation of the seen facts of the present time. Analysis is, moreover, the most effective method of presenting intricate problems to an audience of mature experts, from whom the author desires a critical consideration rather than a passive acceptance of his conclusions. Analytical presentation would therefore here be preferable to inductive presentation of the features of the Front Range of the Rocky Mountains, if the choice lay only between these two methods; but practically all the problems that we encountered had already been solved, inductively or analytically, elsewhere; and what we wished to do was not to discover new explanations for the already explained things that we saw, but to use the known explanations in our descriptions; and for this purpose analysis is only a prerequisite. Furthermore, analytic presentation at the best tends to carry the reader's attention away from present features, and direct it to past conditions and processes from which present features have been evolved; and in this respect analysis is associated more with geology than with geography. Only by conscious effort and continued study are the explanations that are reached through analysis made familiar enough for use in geographical descriptions; and this effort leads us to the systematic method of presentation. It will therefore serve our present object to use the results gained by analysis, instead of here demonstrating them by analytical study.

Historical presentation serves a useful purpose in bringing forward the work of earlier geographers, even though their knowledge was necessarily more limited than ours. An essay of this kind, in which the object is simply to show the successive stages in the approach to our present knowledge, rather than to emphasize present knowledge, is more nearly associated with history than with geography; but when its intent is to bring out clearly the present status of a problem by following the line of its development and making appropriate citations from the work of earlier investigators, it has great geographic value. In the present instance, however, an historical presentation of exploration in the Rocky Mountains of Colorado would be of little service in describing the mountains themselves; and an historical review of the gradual development of the various problems there encountered would lead us too far from our local subject. Hence the historical method will not be followed.

Systematic study of various kinds of things is essentially the successor of observation, induction, analysis, and historical review, and as essentially the precursor of regional study; for it is by means of the systematic classification of results already gained that the geographer who wishes to undertake regional work equips himself with a varied assortment of standardized ideal types, each of which he strives 
to conceive as the mental counterpart of possible real things, and all of which he strives to arrange in a well-considered order; and it is by means of systematic presentation that he reveals his equipment to his colleagues, so that they and he can understand each other. Indeed, inasmuch as everything that a geographical observer sees when he visits a new field must be described in terms of previously known mental counterparts, it is evidently desirable that, before a geographer undertakes regional description, his previous experience in observation, induction, analysis, and review should be widely extended, and that the results of his extended experience should be carefully systematized and standardized. Only in this way can he insure a conscious return from his geological analysis of past processes, and from his historical review of earlier theories, to a sufficiently direct consideration of the results reached by his analysis and review: only in this way can he thoroughly familiarize himself with a comprehensive and well classified series of standardized explanatory concepts, which shall, as occasion offers, serve as the counterparts of the geographical facts that he encounters in a newly visited field.

Still further, it is essential that the standardized type-concepts with which one geographer is equipped, as well as the terms by which he names them, should be known to his fellow geographers; for otherwise his descriptions will not be understood. If his colleagues think of a hollow when he says " hill," they will gain no correct mental picture of the landscape that he tries to describe. Hence systematic nomenclature is of very great value. Geographical descriptions are indeed successful in direct proportion to the sufficiency of the observer's equipment and to the possession of the same equipment in common by the observer and his hearers. It is in order to serve as sources of common equipment that text-books, from which geographers acquire much of their training, are usually arranged systematically; accounts of related types being placed on neighboring pages, and actual examples being adduced from various parts of the world, in order to attest the correctness of the types. However, our object here is not to provide a standardized equipment in which related types are placed together, but to use an equipment, already provided, in the description of different kinds of real things which occur together in the part of the Rocky Mountains that our party saw during our summer excursion; hence systematic presentation will not serve our needs any better than narrative, inductive, analytic or historic presentation. We shall assume that systematic study and presentation are behind us, and use their results.

Regional presentation then remains as the only method that is at all adequate as a means of describing the varied features of the Front Range in their spacial relations. In adopting this method of pre- 
sentation, we propose, as has already been stated, to give it an explanatory treatment, an advanced grade, and in the first instance at least a condensed form. In such a presentation there is no place for narrative, inductive, analytic, historic, or systematic presentation; nevertheless, training in the processes of observational narration, inductive generalization, analytical explanation, historical review, and systematic classification are all helpful preparatory steps towards the regional goal. This is particularly true in the present case as regards analysis and systematization; for if the features of the region are to be described in terms of their explanation, they or their equivalents elsewhere must have been previously studied analrtically in order that a correct explanation of them shall have been found; and if readers not familiar with the region are to understand the results of such analysis, the results must be stated in terms of standardized explanatory types which are best established, named and made known through systematic presentation.

Rexation of Explanatory Regional Presentation to AnalySIs AND System.-The principle just announced deserves more emphasis. Explanatory regional description necessitates the statement of every element of a landscape in terms of a rational counterpart or type that is already a familiar element of the observer's mental equipment. In order that a correct mental counterpart shall be already provided for a newly obserred external fact, the mental counterpart must have some basis in previous and pertinent observational experience; in order that the mental counterpart shall have a broad ralue rather than only an individual value, it must be generalized by safe induction; in order that it shall have a correct explanatory value, the explanation that it suggests must be grounded on logical analysis; in order that it shall embody the best results of earlier workers, it must include all the successful suggestions that come from historical review; in order that various mental counterparts shall be easily remembered and appropriately named, they must be carefully arranged; in order that they shall be familiar enough for ready use, they must be repeatedly studied; and in order that they shall become generally known to geographers, they must be srstematically presented in appropriate publications. If these essentials are neglected, the types that form a geographer's equipment may be merely isolated empirical items, memorized in hap-hazard order and known only to himself; and such a geographer's regional descriptions will not be particularly accurate or lucid.

It is particularly in the expansion of a systematic series of standardized types of land forms, with which this essay is chiefly concerned, that the mental process of deduction is of great service. After several related facts have been carefully observed and successfully 
explained by the analytical discussion of their mental counterparts, and thus shown to be particular instances of a general case, it is possible by deduction to form mental counterparts of new intermediate examples which shall complete an ideal series of standardized types. The types may then be named by nouns of generic value, and qualified by adjectives of specific value; yet, although thus standardized and named, the types are not made rigid. They are elastic and adaptable concepts, easily modified into endless sub-specific varieties, and thus fitted to serve as helpful counterparts of the endlessly various facts of nature. Yet, elaborate as the mental equipment of a well prepared regional geographer thus becomes, it is easily understood by others, because all its parts are reasonably related. Herein lies the real value of the explanatory as contrasted with the empirical treatment of geographical problems. Explanatory descriptions are not to be commended simply because they are more interesting than empirical descriptions; not merely because they are more easily remembered; not only because they tell a larger truth; but still more because they can be phrased in terms of a thoroughly elaborated equipment of standardized types, and because the series of types employed by the observer can, by reason of well tested relationships, be so readily and accurately understood by those to whom the observer presents his results. This has been proved by experience to be true of land forms, and I believe it to be equally true of all other parts of geography.

Structure, Process and Stage.-There is still a matter of importance to be agreed upon, namely, the scheme by which regional presentation shall be guided, in so far as land forms are concerned. The scheme here adopted is the one which was presented in the Round Table discussion at our Chicago meeting in December, 1907, and for which the proposed name is, the scheme of structure, process and stage. Under this scheme each element of the landscape is treated as the surface of a structural mass which has been carried forward from an initial form to some specified stage of development in the cycle of erosion by the action of some specified process or processes; the form thus genetically described being further qualified as to the strength of its relief and as to the texture of its dissection. Let it however be understood that, while the essential features of this scheme may be thus briefly set forth, no sufficient comprehension of them for practical use in regional description can be gained simply by reading over the foregoing lines. Hence it is not merely on the basis of this brief statement of the scheme, but on the basis of a gradually acquired acquaintance with all its details, which it may be assumed that all our members possess, that the scheme is here introduced without further explanation. 
The Front Range of the Rocky Mountains in Central Colorado: Condensed, Techinical, Explanatory, Regionat Descriptron.-The Front Range in Central Colorado is one of those highlands of disordered erystalline rocks which, after reaching an advanced stage in an earlier cycle of erosion, has been introduced by broad uplift into a new cycle that has now reached a submature stage. Or, to phrase it somewhat less briefly, the Front Range is a highland of disordered crystalline rocks, for the most part resistant schists and granites, whose greater original mass long ago suffered more or less complete planation, depression and burial under a heary series of strata; the compound mass thus formed being dirided by a pronounced monoclinal displacement along a north-south belt into a lower eastern areathe Plains area-and a higher western area-the Mountains area. In the cycle of erosion thus introduced, both areas advanced to old age; the weaker stratified rocks of the Plains area presumably being worn down to very faint relief, the more resistant crystalline rocks uncovered in the Mountains area being less completely worn down to a rolling peneplain, here and there surmounted by eraggy or subdued monadnocks, five hundred to twenty-five hundred feet in relief, irregularly placed, singly or in groups. The region northwest of Denver was then broadly up-arched into a highland attitude, the broad crest of the arched peneplain forming the present crest of the Front Range at altitudes of from ten to twelve thousand feet, while the higher monadnocks that chance to stand on or near the crest reach altitudes of fourteen thousand feet or more; the eastern slope of the arch descending gently (about one hundred and sixty feet in a mile) for some twenty miles, to altitudes of seven or eight thousand feet at the mountain border. During the cycle of erosion thus introduced and still current in the mountainous highlands, the revived east-flowing streams and their wide-spaced, usually insequent branches have eroded young or early mature valleys from five hundred to one thousand feet in depth, which submaturely dissect the highlands, giving them a relief of medium measure and a coarse-textured form; while the upper valleys and the valley heads among the loftier monadnocks along the range crest have recently been severely and submaturely or maturely glaciated. In the same cycle, the weaker strata of the Plains have already reached advanced old age, being thus worn down some five hundred or one thousand feet lower than the mountain border; and since then have entered upon two later episodes of erosion in which broad, shallow valleys have been excavated beneath the still broader undissected interfluves, although the work of erosion in the mountains, contemporaneous with these later episodes, seems to have caused only a narrow deepening of the chief valleys near the mountain border. 
Remarks Upon Condensed Technical Presentatron.-When a statement so condensed as the foregoing is spoken at an ordinary rate of delivery, it can be only imperfectly understood even by an audience of experts, because its full understanding requires the extension of various lines of thought to their corollaries; and for such extension oral presentation allows no sufficient time. Hence a terse and technical statement is less adapted for oral than for printed presentation. Even if printed, it can not be fully understood at the first reading. Its limitations in this respect are fully recognized; its introduction here in so condensed a form has been intentional, in order to show by trial that over-condensation is easily possible.

Apart from the terse style of the statement, attention should be directed to the intentional avoidance of geological matters, as such, in the explanatory phrases. Nothing geologic is mentioned that does not bear strongly on the explanatory description of the mountains. The crystalline rocks of the Front Range are commonly regarded as Archean, but for the geographer this date is unimportant; sufficient is it for him to know that the Front Range consists of " disordered crystalline rocks, for the most part resistant schists and granites." Knowing this he can easily infer the kind of stony soils that must cover the broad surface of the highland peneplain; he is ready to understand that the denser granites, where little jointed, will form craggy monadnocks, while the more fissile schists will be rounded into subdued forms and cloaked with creeping angular rocks and scraps; he is prepared to imagine that ragged ledges must crop out on the sides of the younger valleys of the later cycle, eroded beneath the uplifted and soil-covered peneplain of the earlier cycle, even though no mention of such soils and ledges is made. The rocks being of disordered structure and generally resistant, the geographer can infer that no pronounced trends are to be seen in the arrangement of the residual reliefs, and this inference is afterwards confirmed by the explicit statement that the subdued monadnocks are "irregularly placed, singly or in groups," and that the branch valleys are "usually insequent."

A geologist would undoubtedly specify the Paleozoic and Mesozoic dates of the heavy strata which were spread over the worn down and subsiding crystallines, and which, before the monoclinal displacement took place, presumably extended over much of the present Mountains area, although their truncated and worn-down surface is now restricted for the most part to the Plains area; but the addition of the terms, Paleozoic and Mesozoic, does not aid in picturing the present landscape. True, these geographically irrelevant terms enable a reader who has geological inclinations to correlate the Plains strata with strata of similar age elsewhere, and the terms thus have geological importance; but they do not aid a geographer in conceiving the present landscape of the Plains. 
Graphic Aid in Gegoraphical Presentation.-It has already been explicitly recognized that a statement so terse as that given above regarding the Front Range will ordinarily be imperfectly understood by hearers or readers. But even a condensed statement may be made much more intelligible by the use of a simple device; namely, a correspondingly condensed diagram, in which the essential features of the region concerned are as much simplified and compressed graphically, as they are simplified and compressed verbally in the terse explanatory description; all the better if the diagram is designed to illustrate as many cycles of evolution as are helpful in understanding the explanatory description. This is again no norelty. It is well known that there are many geographical matters which are better presented pictorially, cartographically, or diagrammatically than verbally. Hence it is just as important to study the proper and effective use of various forms of graphic presentation, as it is to study the values of different methods, treatments, grades and forms of verbal presentation.

Large scale maps are unequalled as a means of empirically presenting actual features in their areal relations. In this respect the maps of the Blackhawk, Boulder, Central City, Georgetown (these on scale, 1:62.500), Canyon City, Castle Rock, Denver, Pikes Peak and Platte Canyon quadrangles (these on scale, 1:125,000) are of great service in presenting the features of certain parts of the Colorado Front Range. Good photographs and carefully drawn sketches from well chosen points of view have rastly greater power than words in the presentation of such parts of a district as can be seen from a single point. Diagrams have another and quite a different value. They do not attempt to present the actual features; they are often drawn as if from unattainable view-points; they are, at their best, the graphic equivalents of the standardized mental types, in terms of which the verbal presentation is couched. In this respect their value is altogether different from that of photographs or sketches of actual things. Diagrams are translations of simplified mental concepts into graphic language.

Diagrams have a great value, in that they can be easily apprehended and remembered. Their parts can be seen in systematic relationship, so that they and the whole which they constitute can be easily named. Thereafter the names bring the parts to mind, and also the relations in which the parts stand to each other. It may therefore be fairly maintained that the explanatory description of a trpe form ought first to be illustrated by a diagram of the ideal form, simplified to about the same degree as the verbal description, and only afterwards by a picture of a corresponding actual form. When it is remembered that all verbal descriptions give only the merest abstracts of 


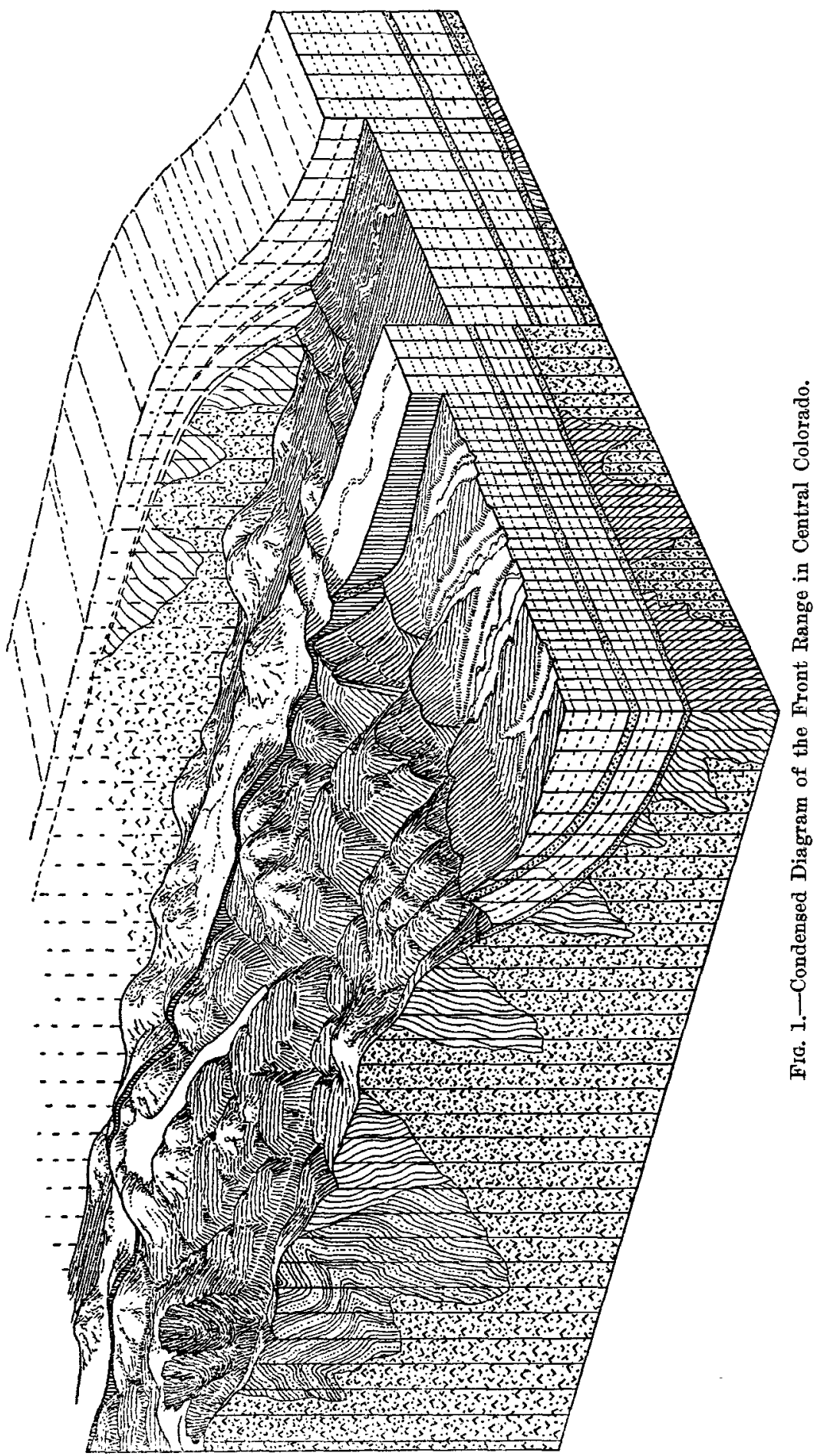


the facts of nature, it may be better understood why their graphic equivalents are simplified and compressed diagrams, from which all manner of unessential complications and details have been intentionally omitted. Let us now make the experiment of adding a condensed graphic illustration to the condensed verbal description previously given.

Condensed Technical Presentation and Condensed Diagram of The Front Range.-The Front Range of the Rocky Mountains in Central Colorado is a highland of disordered crystalline rocks, for the most part resistant schists and granites, as shown in the foreground block and section of Fig. 1. The originally greater rock mass long ago suffered more or less complete planation, depression and burial under a heavy series of strata; the compound mass thus formed being divided by a pronounced monoclinal displacement along a northsouth belt, as in the faint-lined background block of Fig. 1, into a lower eastern area-the Plains area-and a higher western area-the Mountains area. In the cycle of erosion thus introduced, both areas advanced to old age, as in the second, darker-lined block; the weaker strata of the Plains area at the east (right) end of the block being presumably worn down to very faint relief, the more resistant erystalline rocks uncovered in the Mountains area being less perfectly worn down and appearing as a peneplain, here and there surmounted by craggy or subdued monadnocks, five hundred to twenty-five hundred feet in relief, irregularly placed, singly or in groups. The whole region was then broadly up-arched into a highland attitude, as in the slightly shaded third block of the diagram; the broad crest of the arched peneplain forming the present crest of the Front Range at altitudes of from eleven to twelve thousand feet, while the higher monadnocks that chance to rise on or near the crest reach altitudes of fourteen thousand feet or more; the eastern slope of the arch descending gradually (about one hundred and sixty feet in a mile) for some twenty miles, to altitudes of seven or eight thousand feet at the mountain border. During the cycle of erosion thus introduced and still current in the mountainous highlands, the revived east-flowing streams and their wide-spaced, usually insequent branches have, as in the largest or foreground block of Fig. 1, eroded young or early mature valleys from five hundred to one thousand feet in depth which submaturely dissect the highlands, giving them a coarse-textured form and a relief of medium measure; while the upper valleys and valley heads among the loftier monadnocks along the range crest have recently been submaturely or maturely glaciated, one glacier being represented on the further side of the foreground block, and some evacuated cirques and overdeepened troughs being shown on the nearer side. In the same cycle the weaker strata of the Plains have already 
reached advanced old age, being thus worn down some five hundred or one thousand feet lower than the mountain border; and since then have entered upon two later episodes of erosion in which broad, shallow valleys have been excavated beneath the still broader undissected interfluves, as shown in the right foreground. The work of erosion in the mountains, contemporaneous with these later episodes, seems to have caused only a narrow deepening of the chief valleys near the mountain border.

Remarks Upon Illustrated Technical Presentation.-A verbal statement is so much illuminated by the addition of a condensed diagram that all the labor of designing and drawing is fully repaid. Yet, with its advantages, a diagram has certain disadvantages. It is too specific; for example, the figure here given shows in the foreground section a particular kind of disorder in the structure of the crystalline rocks, instead of leaving the disorder undefined; it indicates too positively in the background block the undetermined overlap of the Plains strata upon the ancient planation surface of the crystallines in the uplifted Mountains area. The verbal statement properly enough leaves these features vaguely defined; the diagram necessarily exhibits them with undesirable definiteness. But on the whole the advantages of a diagram far outweigh the disadvantages; so greatly, indeed, as to warrant the recommendation that some moderate practice in the construction of diagrams should be made part of the training of all geographers who propose to reach proficiency in the analytic, systematic and regional methods of presentation. As far as outline diagrams of the sort here considered are concerned, the common excuse, "I can not draw," reveals an essentially inefficient training. It was once remarked to me, in effect, by a professor in a European university: "That method of giving diagrammatic illustration to systematic and regional treatment is all well enough for those who can draw, but I can't." I protested that he must learn to draw diagrams by repeated practice. A year or so later he wrote me: "I am now constantly using diagrams in my lectures, and with real success."

Explicit Statement of the Corollaries implied in a CoNdensed Technicat Statement.-A condensed technical description may be expanded by an expert reader, if he gives the time to it, so that its lines shall grow into pages; but when thus expanded it is still only of a general nature; it lacks quantitative data and specific details, and is wanting in the local color that comes from the mention of particular instances. Moreover, the mental effort required for the correct expansion of a condensed statement is more than many readers care to give; they are warranted in the feeling that it is for the writer rather than for them to develop more explicitly the ideas that are implicitly contained in a terse statement, just as the corollaries 
in a text-book of geometry are usually explicitly stated after their implicit presentation in a theorem. The terse statement will then serve as a concise introduction to what follows, and, as far as its compacted phrases are made intelligible by the aid of appropriate diagrams, will take the place of an outline of contents, in view of which each topic, as it is more fully treated, will be all the better apprehended in its proper relation to every other topic.

Subdivisions of the Front Raxge.-It is usually necessary, in passing from a very general to a more specific description, to make some use of place names. The names thus far used-Rocky Mountains, Front Range, Colorado, Denver-are assumed to be well enough known not to need definition; the names introduced in this section are, on the other hand, assumed to be unknown to most readers or, if known at all, not to be known in relation to the features here discussed; hence they can not, without further definition, be properly used as guides to the location of other unknown features. The ordinary habit of using the names of mountains, streams, villages, and so on, without previously locating these smaller features with reference to known larger features, seems ill-advised: it is often a hindrance rather than a help to the reader; it should be avoided instead of adopted. If a condensed description, given at the outset as an introduction to what follows, is a correct generalization of a district, then a systematic expansion of it ought to lead easily to the recognition of natural subdivisions, within each of which certain smaller features can be located with respect to the larger features; and after this has been done, the names of the subdivisions and of the smaller localities within them can be helpfully employed when need arises, all the better if accompanied by an outline map.

The underlying principle here to be observed is to avoid the empirical use of unknown place names, even if shown on an empirical map, as guides to the location of unknown natural features, and to insist as far as possible on placing every smaller locality in its proper relation to the larger localities that are indicated in the introductory explanatory description of the whole region concerned.

The highland of the Front Range is easily recognizable orer a north and south length of some two hundred miles; but we are here concerned only with about one hundred and twenty-five miles of its southern part, included in Fig. 2. Beyond the southern end of the Front Range highland, the Rocky Mountains are continued in the Wet Mountain and other ranges, in which the highland quality is not apparent. The end of the highland is near an embayment due to an irregularity in the usually north-south monoclinal displacement by which the Mountains area is separated from that of the Plains; and here the range is cut across by the deep canyon of the east-flowing Arkansas 
River, which rises in an intermont basin some forty miles to the west. Canyon City lies at the mouth of the Canyon-the so-called Royal Gorge of the Arkansas-and the industrial city of Pueblo lies on this river forty miles to the east on the Plains.

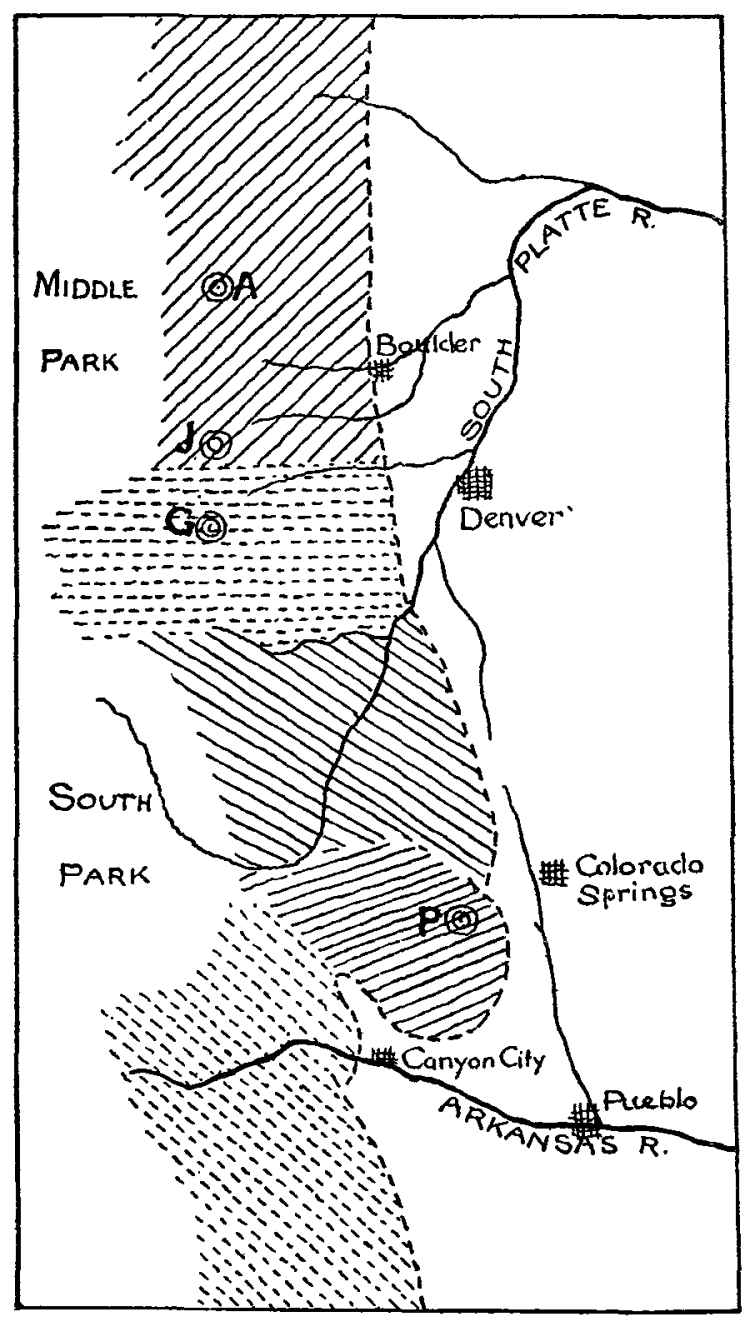

FIG. 2.- Outline map of the Front Range in Central Colorado.

About thirty miles north of the Canyon City embayment is a smaller embayment of similar origin: Manitou lies at its inner angle, and Colorado Springs, five miles to the east. The highland mass between the two embayments may be named after the commanding monadnock of Pikes Peak (14,108 feet), which gains an unusual promi- 
nence because it stands near the front of the highland, and because the highland was here given an unusually full measure of uplift at its front. The Pikes Peak highland is about fifteen miles wide; it descends but little on the west to the lofty basin-plain of South Park, drained northeastward by the South Platte; next westward rises the Park Range, then follows the intermont valley of the upper Arkansas River, already mentioned, and beyond this is the Sawatch Range, with the College Peaks. The South Platte River may give its name to the Front Range highland that it traverses, thus defining an extension of about sixty-five miles northward from the Manitou embayment. On the Plains near the mid-front of this division is a village, chiefly occupied as a summer resort and named after an artificial pond, known as Palmer Lake: this point is significant as being the divide between two streams, Monument Creek, which with Fountain Creek flows southward about sixty miles to the Arkansas at Pueblo, and Plum Creek which, with the South Platte that it joins, flows eighty miles northward, before the river turns eastward at the agricultural city of Greeley. Thus the mountain front is adjoined by what seems to be a pair of broad and shallow subsequent valleys, presumably excavated on weaker strata, and apparently inclosed on the east by a low escarpment of harder strata. The valleys may reach a width of five or ten miles or more; but where their heads come together they are narrowed so that the escarpment and the higher part of the plains ( 7,500 feet) that it borders extend close to the mountain base, except for the small depression in which Palmer Lake lies. Here the mountain highland, at an altitude of nine thousand feet, is only fifteen hundred feet higher than the Plains, a few miles to the east.

North of the South Platte division is a particularly mountainous part of the Front Range highland, including Grays, Torreys, Evans, James and other lofty monadnocks; this division is twenty miles or more in north-south extent, and will be called the Georgetown district, after an important mining town in its center: it is drained by Clear Creek, on which at the mountain base lies Golden, the seat of the State School of Mines; while Denver, the capital of the State, lies fifteen miles east of the mountains, near the junction of Clear Creek with the Sonth Platte. Next, for about twenty-five miles, comes what may be called the Boulder division of the highland, drained by South, Middle, and North Boulder Creeks; at the gorge-mouth of one of these creeks lies the town of Boulder, the seat of the State University. A similar division next north is drained by St. Vrains Creek. To the west of both of these divisions the highland descends into the intermont basin of Middle Park, drained westward by the Grand River to the Colorado; hence the crest of the Front Range here is the Continental Divide. Its culminating summits are Mt. Arapahoe $(13,520$ 
feet) near the head of St. Vrains Creek, and Longs Peak (14,271 feet), which rises over the highland some miles farther north, beyond the district here studied.

The Highland Peneplain of the Front Range.-The condensed explanatory description of the Front Range clearly indicates that its dominant feature is the elevated peneplain or highland, which gently ascends from the mountain border to the broad mountain crest; a highland surmounted here and there by craggy or subdued monadnocks, irregularly placed, singly or in groups; a highland submaturely dissected by submature or mature valleys. The highland must therefore be imagined as an elevated rolling surface between the monadnocks that rise above it and the valleys that sink below it; for even where typically developed a peneplain must not be conceived as a plain. In the neighborhood of the monadnocks its inequalities often constitute low hills, which if they occurred everywhere would make the peneplain unrecognizable; but in other districts the gently rolling upland is so well developed and so well preserved that its interpretation is beyond doubt, and its imperfections elsewhere thus come to be understood in their true value. A characteristic view of a well developed part of the highland peneplain in the Boulder district is given in Plate Ia.

Let it be explicitly noted that the reason for describing the highland as an uplifted peneplain is not merely that it is now the fashion thus to describe such forms, for it was once similarly the fashion to describe them as uplifted plains of marine abrasion. Fashion is a poor guide to scientifie decisions. The reasons for excluding marine action and for regarding the highland as an uplifted peneplain of normal erosion are, first, that its undissected form, as far as that can be reconstructed from its present dissected surface, must frequently have had a gently rolling surface, such as an old surface of normal, subaerial degradation should have, and not a smooth surface such as a plain of marine abrasion ought to have; second, that no line of ancient sea cliffs is found, separating a smoothly abraded surface from a neighboring area of hilly land, such as the theory of marine abrasion either tacitly or explicitly presupposes; and third, that none of the numerous monadnocks exhibit sea cliffs on their exposed side, as they should do if the surrounding surface had been planed off by sea waves. If the highland were stated to be an uplifted plain of marine abrasion, the occurrence of all these features would be implied. The mere statement that the highland is an uplifted peneplain ought therefore immediately to indicate that it possesses none of the above-specified features of a plain of marine abrasion, but that it exhibits many or all of the characteristic features of a plain of subaerial degradation. It is in problems like this that the common and familiar posses- 
sion of a well established series of ideal types by well trained geographers goes so far towards making geographical descriptions effective.

The dissection of the peneplain being described as submature, even though some of its valleys are mature, it must be inferred that significant areas between the larger valleys still remain undissected; yet in the neighborhood of these valleys, many small ravine heads must be imagined as already encroaching upon the highland surface. In the mountains of the Boulder division, northwest of Denver, where the undulating skyline of the highlands is repeatedly seen as one walks over the highlands, the westward ascent of the peneplain, about one hundred and sixty feet in a mile, is easily recognized, especially where the highland is free enough from monadnocks to expose long stretches of its surface in a single view. One part of the slanting highland in this district, standing at about ten thousand five hundred feet altitude, is known as Caribou Flats, C, Fig. B2; if neighboring and similar slanting highlands are called Bryan Mountain, $\mathrm{R}$, and Chittenden Mountain, $H$, this probably means only that they were named as seen from the valley bottoms.

So distinct an inclination as one hundred and sixty feet in a mile is much stronger than that of a peneplain at the time of its degradation, and must be due to tilting at the time of elevation. This is easily proved by reverting for a moment to analysis. Note first that the valleys of several streams in the district northwest of Denver become somewhat deeper as they are followed westward into the highlands; hence the eastward slope of their streams is not so strong as that of the highland surface; yet these submature streams, heavily loaded with coarse waste, must have a decidedly stronger slope now than their ancestors had on the lower lying peneplain; all the stronger, therefore, is the eastward slope of the uplifted peneplain than was that of the peneplain before its uplift: hence the uplift was here accompanied by gentle eastward tilting. From favorable points of view, as for example, from the cirque walls at the head of Middle Boulder Creek, M, Fig. B2, one may look eastward down the slope of the highlands, as in Fig. E3, and see that the eastward projection of the highland surface would intersect the Plains some twenty or thirty miles east of the mountain base. Hence the slanting or arching uplift, whereby the mountain belt was introduced into the current crele of erosion, was decidedly greater in the mountains than farther eastward; indeed, the uplift may have soon died out in that direction, just as the much earlier monoclinal displacement did.

It is interesting to note that the highland as a mass, from the base of the mountain front to the crest of its arched uplift, occupies the zone of altitude within which tree-growth is here possible. The Plains, sloping gently eastward from the mountains, are treeless, owing to 
aridity. The monadnocks which rise above eleven thousand two hundred or eleven thousand four hundred feet are for the rest of their height above the timber line, owing to low temperature. The mountainous surface between these limits usually has an open tree-growth, close-set forests being exceptional.

Southwest of Denver in the South Platte division, the slant of the highland is less marked, and in some views-for example on the highland, Fig. A2, west of Palmer Lake, between Denver and Colorado Springs, the skyline seems to be essentially level; much more so in the actual view than would be inferred from the crowded contours of the Platte Canyon map-sheet. It was in this part of the range that we saw the smoothest horizon at altitudes of ten or eleven thousand feet; it was rarely interrupted by monadnocks, although the foreground of some views was rather broadly interrupted by wide-open valleys, of which that of the South Platte at Buffalo, Fig. A1, may be taken as an example. The destruction of the open forest by fire has disfigured many views. In this district the uplift of the peneplain must have been very even. It may be noted that here, as well as in the Boulder district, the present altitude of the peneplain must not be taken as a direct measure of its uplift; for the peneplain before uplift may have had an altitude of several thousand feet, by reason of the great length of the rivers by which it was drained. The peneplain may have even then deserved to be called a highland, rather than a lowland; it was surely at a significant altitude above baselevel, and hence ought not to be described as having been "baselevelled." Cvijič has called attention to this corollary of the theory of peneplanation and has coupled therewith Philippson's principle, in accordance with which a peneplain may be dissected without suffering elevation, provided the district between it and the sea is depressed or drowned. In the absence of evidence regarding such depression, and in view of the tilting of part of the Front Range highland, as proved above, uplift of the highland itself appears probable; but the uplift may not have measured more than some five thousand feet.

West of Denver in the Georgetown district the monadnocks are often so numerous, so closely set and so high that the elevated peneplain can hardly be recognized; yet it was from a study of this district that an excellent statement of the physiography of the Front Range was prepared by Ball ${ }^{1}$, who for the first time fully set forth its character as a two-cycle mountain mass. Far north in Wyoming the peneplain is remarkably well developed, as one may judge not only from the disappointment of the casual traveller who sees no mountains

\footnotetext{
${ }^{1}$ S. H. Ball (with J. H. Spurr and S. H. Garrey) Economic Geology of the Georgetown quadrangle, Colorado. Prof. Paper. 63, U. S. Geol. Surv., Washington, 1908, 31-35.
} 
as he crosses the crest of the range on the Union Pacific Railroad, but still better from the explicit description by Darton in Folio 173 of the U. S. Geological Survey. Far south, beyond the canyon of the Arkansas River, the even skyline was not apparent from our points of view in that district; it seemed as if the mountains there had been uplifted in a more disorderly manner at the beginning of the present cycle of erosion, and that their crests had been more deeply sculptured during the present cycle than is the case farther north.

The extension of the peneplain west of the range crest is intentionally left unmentioned. Our route did not enable us to determine the manner in which the highland descends into the broad and elevated basins known as South and Middle Parks; but our inference was that, while irregular warping of the mountain mass at the time of its last uplift may have contributed to the smaller initial altitude of the park areas, their altitude today is in large part the result of the erosion of bodies of weaker rocks-similar to those of the Plains-which occupied basin-like structures probably formed in association with the monoclinal displacement by which the present mountain area was first differentiated.

It follows from the foregoing that the Front Range belongs in that lately recognized and rapidly growing class of mountains, in which the deformation that produced their disordered structure has little or nothing to do with their present form. The greater deformation of the crystalline rocks in the Front Range was produced long before their ancient planation; and hence long before their burial under the covering strata now seen in the Plains. The strong monoclinal displacement was followed by peneplanation, except where the monadnocks survive. The present form and altitude of the range is therefore not due to the monoclinal displacement of the compound mass, still less to the remotely ancient deformation of the crystalline basement, but to the broad and simple up-arching of a much later date. In so far as the range is really mountainous, this character is to be associated with the monadnocks that survived the cycle of peneplanation, and with the valleys that have been eroded since the peneplain was elevated. As a matter of fact, many a view even at altitudes of ten or eleven thousand feet is by no means mountainous, but monotonous instead, as on the highland (Figs. C3, C4) west of Colorado Springs and northwest of Pikes Peak (Fig. C5), where it is crossed by the Colorado Midland Railroad. Here, however, part of the present simplicity of the landscape is due to a heavy cover of gravel, now late-maturely dissected to small relief, which hides the rocks of the highlands for many miles. Cross $^{2}$ has suggested that these gravels are associated with glacial

${ }^{2}$ W. Cross, Folio 7, Geol. Atlas of the United States. U. S. Geol. Surv., Washington, 1897. 
action, but as they are some miles distant from the nearest signs of glaciation in the cirques and moraines of Pikes Peak, the gravels seemed to us more probably associated with obstruction of drainage by warping at the time of uplift.

A brief systematic digression may here be made with profit.

Highlands and Mountains Treated as Uplifted and Dissected Peneplains.-The attempt to treat mountains as the result of erosional processes, working on uplifted masses which reflected their disordered internal structure in an extremely irregular initial surface, has been attended with difficulty; a difficulty indeed so serious that this chapter of the physiography of the lands has generally been treated unsystematically, except for a few special cases of simple deformation, such as block mountains and domed mountains. The difficulty has, however, been very much reduced by the studies of the past twenty years. It has been found that most mountain ranges of the world are not to-day in a first cycle of erosion, initiated by the great deformations to which the extreme disorder of their structure is due; but that, in a large number of investigated ranges, the first cycle of erosion, presumably introduced by the production of their disordered internal structure, had ages ago advanced far towards its close; and only after its initial inequalities had been thus almost completely removed, even to their peneplanation in many cases, has a new cycle been introduced by much simpler movements than those of the primary deformation.

All such mountains are open to relatively easy systematic treatment; for their initial forms in the current cycle are the subdued and simplified forms developed in the late mature or old stage of the preceding cycle, now more or less uplifted, warped, dislocated and tilted, but not again thrown into strong disorder. On those simple forms, the rivers, perhaps partly persistent in courses consequent on initial deformation, but as a rule adjusted to the deformed structures on which they had worked so long, are revived into new activity, and develop a new mountainous form by the incision of deep valleys. "Mountains of circumdenudation" is therefore no longer a term to be applied only to dissected plateaus of horizontal structure: it applies equally well to many ranges of deformed structure, and this important principle was recognized for the Front Range by Marvine in 1873. The scheme for the systematic treatment of mountain forms has thus been most effectively as well as unexpectedly aided by the facts of nature.

Two-Cycle Modntains.-Many analytical discussions of mountains, which bear evidence of two cycles of erosion, might be instanced. The earliest example to be recognized is in Wales; Ramsay sixty years ago explained the comparatively even Welsh uplands, in which the 
valleys of to-day are carved, as an uplifted plain of marine erosion. Singularly enough no detailed account of this interesting district has been prepared by later British students of land forms. The Highlands of Scotland are perhaps more familiar examples of two-cycle mountains than the uplands of Wales, because of the attractive description that they have received at the hand of Sir Archibald Geikie. As in Wales, marine erosion was formerly held accountable for the broad truncation of the disordered Highland structures and the reduction of an ancient disordered mass to a comparatively eren surface, in which, after elevation to its present altitude, the existing ralleys have been carved; but British opinion seems now to be generally in favor of attributing the undulating truncation of the Scottish Highlands, as well as of the Welsh uplands, to normal erosion during a former lower stand of the region, rather than to marine erosion.

The rolling highlands of the Slate Mountains which border the gorge of the Middle Rhine were explained as surfaces of marine abrasion by the older German geologists and geographers; in this respect they followed the lead of von Richthofen, whose attention had been directed to the broad truncation of disordered structures during his studies in China: but in Germany, as in Great Britain, a number of the more recent observers ascribe such uplands as those of the Slate Mountains to normal peneplanation.

In the central highlands of France various observers have recognized a well developed peneplain, more or less dissected: one of the best accounts of this region concerns its northwestern part, the Limousin, in which the dominant peneplain has lately been described by Demangeon as surmounted by remnants of a still older peneplain in certain highland areas, and which may therefore be regarded as involving a three-cycle development since the last disorderly movement of its rocks. Still more recently, Briquet has studied the forms of the present landscape in the southeastern part of the same region, which he believes represent four successive cycles of erosion, separated only by simple changes of level; the earliest cycle being represented by an elevated peneplain on which the valless had reached extreme old age; the latest cycle br narrow, steep-sided young valleys.

Brückner and Machatschek regard the Jura as in a second crcle, following a first in which the folded mass was reduced to moderate relief. Even in the Alps there are many traces of rast erosion on enormously deformed structures, before the torso thus prepared was warped into its present attitude and thus introduced into the cycle of erosion now current: the simplest line of eridence to this conclusion is found in the tame manner in which enormously deformed and deeply eroded structures disappear with small relief under the modern deposits of the plain of the Po. 
High standing, deeply dissected peneplains are described by de Martonne in the Transylvanian Alps; Danes, Cvijič and others have found lower standing peneplains in the Dinaric Alps. Various authors, among whom Reusch, Richter, Vogt, Nussbaum and Machatschek may be named, have interpreted the highlands of Norway as an uplifted peneplain in various stages of dissection. The southern extension of the Ural Mountains is still a low-lying peneplain, undissected over large areas; but farther north uplift and dissection of what seems to be part of the same peneplain produces a topography of sub-mountainous relief. The Tian Shan and the Pamir exhibit numerous and extensive highland peneplains, more or less perfectly developed before uplift to their present altitude, and more or less completely dissected since then; the observers here to be referred to are Friederichsen, Keidel, Huntington, R. W. Pumpelly and the present writer. Lofty highlands of erosion in the northwestern Himalayas are described by Oestreich; Loczy and Filchner describe similar forms in Tibet, though without calling very explicit attention to their meaning. Willis has given abundant description and discussion of high standing, dissected peneplains in the mountains of China. Lately de Martonne ${ }^{3}$ has summarized these and other records in an important article on the evolution of the relief of central Asia.

Andrews describes dissected peneplains in the highlands of northeastern Australia. Bornhardt, Uhlig and Jaeger describe highland peneplains, more or less dissected, in equatorial east Africa; Passarge and Hassert in southwest and west Africa. Keidel reports uplifted peneplains in the eastern members of the Argentine Andean massif, where they are of greater extent and perfection than those he had previously seen in the Tian Shan. Bowman describes a lofty peneplain in the Bolivian Andes, little dissected in its more arid areas, deeply dissected on its rainy eastern slope.

In our own country the evolution of the Appalachians in two or more cycles of erosion has been repeatedly discussed. The Laurentian Highland, hardly a mountainous region though often so represented on maps, is regarded by Willson as a vast peneplain; and the highlands of northern Wisconsin are similarly treated by Smyth and Weidmann. The Sierra Nevada of California is generally believed to be a more or less faulted and tilted block, an uplifted part of a vast peneplain, now sloping westward from the strong and somewhat elaborately dissected escarpment that it presents to the basin of Nevada. In that basin, Louderbach has given a convincing demonstration of two-cycle origin for at least one of the Basin Ranges, thus substantiating, as far as one example among many can, the view long

\footnotetext{
${ }^{3}$ E. de Martonne, L'évolution du relief de l'Asie centrale. La Géogr., XXIII, 1911, 39-58.
} 
ago presented by Gilbert. Diller has found peneplains at various altitudes in the mountains of Oregon; Willis describes the Cascade Range as an elaborately dissected peneplain; Dawson some years ago recognized an uplifted and deeply dissected peneplain of wide extent in the highlands of western Canada, concerning part of which Camsell has recently given some details. Gilbert regards the approximate equality of mountain altitude in parts of Alaska as suggestive of a two-cycle origin for some of the ranges that there border on the sea. Finally, Marvine clearly recognized the two-cycle origin of the Front Range, as is shown in the citations from his report of 1873 at the head and on later pages of this article, though he did not use the term "cycle" and though he was mistaken in identifying the peneplain of the Highlands with the planation surface of the mountain front.

Systematic Equipment With Standardized Types for the Explanatory Description of Mountains.-The analytical study of all these different highlands and mountains has brought forward good reasons for explaining their existing forms as the product of at least two cycles of erosion, the earlier one of which may have been initiated by the deformation which gave the masses their deformed structure, while the later one was introduced by relatively orderly uplift. It is therefore full time that conscious attention should be directed to a well planned arrangement of the ideal types, which shall be the mental counterparts of these many actual examples; and to the completion of a well developed, systematic series of ideal types, various intermediate members of which are developed deductively in view of the general principles established by analysis regarding two-cycle mountains. The most significant matters to indicate are first, as always, the general structure of the mass; then the stage reached in the earlier cycle before renewed elevation; next the character and amount of elevation; and finally the stage reached in the later cycle after elevation. An elementary graphic treatment of this problem is attempted in my "Practical Exercises in Physical Geography." It may be noted in passing that the term "cycle" finds unexpected justification in those two-cycle mountain ranges, which began in a peneplain very similar to the peneplain in which they will end.

There can not be the least question that the possession of some such series of ideal types, systematically arranged, conveniently named, and thus standardized for easy and immediate use in the description of new regions, greatly strengthens the equipment of a modern geographer, as compared to that of a geographer of the older school. Surely when a modern geographer, thus equipped for mountain exploration and description, returns from a visit to a two-cycle mountain range, he need not, when he is writing for other modern geographers, gradually, inductively, laboriously introduce his problem; he need not even 
repeat its analysis; he may at once use the results of analytic and systematic study, and draw upon the equipment that such study has furnished for his descriptions of what he has seen. Two-cycle mountains today constitute a well established class, and the types in terms of which they may be described are in some fair degree standardized. To discuss matters of this sort before using them would be, among expert geographers, about the same as demonstrating over again in an essay on stratigraphy intended for expert geologists the familiar principle that two periods of formation and a period of erosion are indicated by an unconformity.

The discussion of peculiar and exceptional cases is of course always in order; but standardized cases can be dealt with more promptly. A modern geographer may therefore in his regional studies make immediate use of standardized type forms of two-cycle mountains when he has to deal with that class of forms, because his types are abundantly supported by widespread observation, warranted by repeated and critical analysis, and conveniently arranged by systematization. For example, he need merely say: "Here is another twocycle mountain range which reached advanced old age in its earlier cycle, but which is still submature in the present cycle." . His readers, similarly equipped with a scheme of standardized types, will immediately understand the essence of what he means. Both writer and readers may then easily pass on to the next subject.

The Monadrocks. - The concept of monadnocks surmounting a peneplain is one of the simplest that is to be encountered in the systematic study of land forms. Residual reliefs of this class are to be conceived as determined by a more or less pronounced excess of resistance, due to some peculiarity of composition or of structure: but it should be understood that various factors, besides those which are indicated by difference of color of geological maps, may suffice to determine the survival of monadnocks in the slow process of inorganic natural selection, which operates during the long continued later stages of an uninterrupted cycle of normal erosion. Differences in the attitude or number of stratification or of foliation planes, in the number of joints and other surfaces of separation, in the texture of mineral grains, and in the degree of consolidation, may all contribute to cause a slightly slower degradation of one part of a single rock formation than of another. Mt. Monadnock itself, the type of this class of forms in southwestern New Hampshire, has been described by Perry ${ }^{4}$ as consisting of essentially the same kind of schist as that which constitutes the surrounding uplands which Monadnock surmounts; the survival of the mountain in the cycle of erosion which produced the now ele-

J. H. Perry, Geology of Monadnock Mountain, New Hampshire. Journ. Geol., XII, 1904, 1-14. 
vated peneplain of the uplands is therefore explained by him as due to its initially greater mass, as if it were the survivor of an initial divide: but if Mt. Monadnock were really of this origin, other divides in its neighborhood ought to show a similarly strong relief, and they do not: hence I am still inclined to attribute its survival to excess of resistance as determined by something less manifest than difference of composition.

For residuals due to excess of initial mass, Penck ${ }^{5}$ has proposed the name mosore. Whether any of the residuals of the Front Range highland are of this kind, has not yet been determined. Their distribution seems arbitrary, but it is to be presumed it will be accounted for when the nature of the rocks and their relation to the drainage of the earlier cycle is better understood. In the meantime they will here all be called monadnocks; indeed it may be that the definition of this term should be expanded so as to include both classes of residuals, in view of their similarity of form and of their difficult discrimination.

The monadnocks of the Front Range highlands may in most cases be described by the term "subdued," a term that is peculiarly appropriate for mountains in late maturity or early old age, because it at once suggests the larger forms that they once had, the strong resistance that they have opposed to destruction, their gradual subjugation by the persistent attack of the weather, and the gentle form to which they have been reduced. As in all trpical examples of subdued mountain forms, these rounded dome-like masses are covered with creeping waste, and the texture of their dissection is coarse; that is, the ravines by which they are slightly incised are widely spaced. The form of such domes is hard to sketch, because so few well defined lines are to be seen. One of the best examples of a subdued dome is Bald Mountain, B, Fig. B2, which rises above the well defined highlands in the western and higher part of the Boulder district, apparently reaching an altitude of nearly twelve thousand feet, and yet, as seen from the east, Fig. B1, it bears no marks of glacial sculpture, as if its preglacial form had been unfarorable for the accumulation of snow reservoirs, in spite of its great height. It is photographed in Plate $\mathrm{I} b$.

In certain granitic districts, the monadnocks exhibit fine-textured, craggy forms, with angular outlines and many bare ledges near their tops, and large boulders of decomposition on their flanks. These rugged masses are still too bold to be called subdued. A good example is seen in Sheep Mountain (10,500 feet), Fig. C1, which rises in strong profiles over the eastern and less elevated part $(8,500$ feet $)$ of the district northwest of Denver. Some smaller, unnamed, craggy

'A'. Penck, Geomorphologische Studien aus der Herzegowina. Zeitschr. deut. u. österr, Alpenna, XXXI, 1900, 25-41; see p. 38. 
hills in the same district are shown in Fig. C2. Farther south, the irregular form of three unsubdued residuals that surmount the even uplands over the open valley of the South Platte is indicated by their names, Needle Butte, Long Scraggy and Little Scraggy Peaks, Fig. A1. Plate II $a$ shows a group of such forms.

The difference between the subdued and the craggy forms appears to be dependent on the number of joints or fissures in the rocks. In the more fissile roclss, the whole surface of the dome-like mass comes to be covered with a slow-creeping sheet of coarse rock waste; bare ledges are hardly seen, except where glacial excavation has taken place. In the more massive rocks, which were granites in all the cases that we noted, weathering enters chiefly by the wide-spaced joints, and leaves large unjointed crags standing between widened crevices. Weathering on the face of the crags results in splitting off rock scales which are soon reduced to gravelly waste. Thus rounded blocks frequently stand up in bold forms and ledges.

Exceptionally strong and mature forms were noted in the Tarryall Range of monadnocks near the upper valley of the South Platte, northeast of South Park, shown in the background of Fig. C3; they seemed more vigorously mountainous than any other non-glaciated summits that we noted, but as they were only seen at a distance of several miles, further account of them is omitted. Pikes Peak, Fig. C5, is one of the largest monadnocks.

The prevailing similarity of altitude among the mountains of Colorado has often been mentioned. In Gannett's Dictionary of Altitudes (1899), there are forty-two summits in Colorado between 13,500 and 14,000 feet; thirty-nine between 14,000 and 14,500 feet, and none higher than 14,500. As far as the Front Range in the central part of the State is concerned, the meaning of this accordance of altitude is not far to seek:-it results first from the reduction of the greater mass of the former cycle of erosion to subdued forms of moderate relief, which seldorn rose more than two or three thousand feet over the peneplain that they surmounted; and second, from the simple character of the broad uplift by which the current cycle of erosion was introduced; and to these chief causes may be added a third, namely, a relatively rapid reduction by glacial sapping of any excessive height that the loftiest summits may have had, as will be further shown below. How far this explanation applies in other parts of the State, I am not prepared to assert.

The Valleys. - The valleys by which the highlands of the Front Range are as a rule submaturely dissected vary from very young forms, as in the steep-walled Royal Grorge of the Arkansas River, and from the sub-mature, craggy-sided valleys of various creeks, to the late mature, widely opened valley along certain parts of the South Platte. 
The difference of development and of expression is evidently to be referred to differences of rock resistance. The very young gorge of the Arkansas and the wide-open, late mature valley of the South Platte are, however, both exceptional. The steep walls of the Royal Gorge, often slanting $70^{\circ}$ or $80^{\circ}$, expose almost continuous surfaces of bare rock, and thus afford a superb natural section of the disordered schists and granites; as in all such cases, the master joints exercise much control over the detailed sculpturing of the rock-face. The graded sides of the South Platte raller, Fig. A1, at its wider parts, have moderate declivities of $12^{\circ}$ or $15^{\circ}$. Here the river has a flood plain a few hundred feet wide. The insequent branching of its many little side valleys suggests that if, in the late mature stage here reached, joints and fissures exert any control over their arrangement, the control must be intermittent and imperfect; for there must be many parts of the side-valley lines independent of fissures, and many fissures not developed into valleys.

Most of the normally eroded valleys in the highlands are $V$-shaped in cross-section, as in Figs. A3 and D1, and Plate IIb. The streams are roughly graded; boulder-rapids are common, but ledge-rapids are rare. Most valleys are narrow floored, with little or no flood plain; steep-sided, with many irregular alternations between projecting ledges and graded slopes; and sufficiently sinuous for the production of numerous spurs, whose orerlapping ends soon close the riew along the narrow valley bottom. It goes without saring that the junctions of branch and trunk valleys are at accordant level, except in the upper glaciated regions ; for accordant junctions obtain universally in submature, mature and old valleys of normal origin. Exceptions to this rule are here seen only in small, dry gulches, which may "hang" on the hardest rocks ten or twenty feet over the main torrent of a normal valley.

The depth of the main valleys is less than might be expected, in view of the considerable altitude of the highland. Many valleys are incised only to a depth of six or eight hundred feet; a few reach a depth of one thousand feet; this measure is exceeded only in some of the glacial troughs. The apparent depth is increased in certain valleys which happen to lie so near a monadnock that its slope above the highland level is added to the slope of the valley side below the highland, as is the case on the southern side of the valley of Fourmile Creek, Fig. D1, where Sugarloaf and Bald Mountain rise along side of it. (This Bald Mountain is not the same as the one shown in Fig. B1). Not only are the valleys of moderate depth; they are not likely to become much deeper in future, unless in short stretches near their headwaters, for the further deepening of the valleys in the mountains depends largely on the deepening of the valleys on the plains; and inasmuch as these are all already at grade, their further deepen- 
ing can be accomplished only when the mountain streams bring less load to them; and that is a very remote contingency, hardly to be realized until the mountains themselves are subdued in a late mature stage of the cycle through which they are now passing.

The valleys are seldom wide enough to allow the easy construction of wagon roads; the picturesque road up Middle Boulder Creek being a departure from the rule. The usual habit of the roads of earlier date was to ascend the mountain front and to traverse the highlands; but farther in towards the crest of the range, wagon roads follow the broadened floors of the glaciated troughs. Railroads of later date often enter the gorges from the Plains.

In the Georgetown and Boulder districts, west and northwest of Denver, most of the larger creeks pursue eastward courses, as if they might be consequent on the arched uplift by which the present altitude of the range was produced; but a more plausible explanation regards these creeks as simply revived from the former cycle of erosion. If this be correct, it suggests that the present crest of the range is up-arched along the line of a former divide, which possibly represented a still earlier axis of uplift; but these transcendental questions can not now be resolved.

Two rivers have eroded through-going valleys, which drain areas back of the Front Range; one is the South Platte, which discharges the waters of the lofty intermont plain of South Park, where it has as yet hardly begun to incise its course; the other is the Arkansas, which issues from a deep intermont basin and traverses the Front Range in apparently antecedent fashion: yet the location of this river across the forward part of the range in which the Royal Gorge is incised seems to be related to a saddle of stratified rocks which there formerly lapped over the present mountain crest at a much less altitude than could have elsewhere happened. Indeed the highland in which this gorge is so sharply incised seems to be nothing more than part of the floor of ancient planation, to which the crystallines were reduced before the deposition of the Plains strata, here deformed in an unsymmetrical anticline at the time of monoclinal displacement, but not lifted so high as was usually the case, and now laid bare. There is local evidence in favor of this view, in the presence of patches of the sedimentary beds on the two flanks of the highland, as well as in the relatively even form of the highland at altitudes less than those reached by the highland peneplain elsewhere. When it is remembered that the steep walls of the Royal Grorge indicate an unusual resistance in its rocks, it may be noted that only by regarding the highland adjoining the gorge as a part of the ancient planation surface, less uplifted than usual, can we reasonably account for its moderate altitude.

The tributaries of the highland streams are of typical insequent 
arrangement, as far as our observation went. This might be expected from the absence of trends in the distribution of the monadnocks. A characteristic feature of the tributary valleys is that they are usually of more mature expression than the main valleys which they join. This may be regarded as a normal, expectable feature; for inasmuch as the action of the weather, by which valley sides are worn back to graded slopes, will be at essentially the same rate all along the valley courses, it follows that, other things being equal, where the streams are largest and cut down their ralless most rapidly, the valley sides will be steep; while where the streams are of small volume, their downward erosion is slower, and the ralles sides there may be weathered back to a graded slope about as fast as they are deepened.

The two episodes of renewed erosion, by which broad valleys have been excavated in the Plains forward from the mountains, are not always recognizable in the forms of the valleys in the mountains. Hence it may be supposed that the renewed valley deepening, as permitted by these reviving episodes, has been accompanied by sufficient widening to destroy all traces of the more mature preëxistent valleys. The only distinct exception noted to this rule is in the gorge of South Boulder Creek, Plate III $a$, which issues from the mountains where they are bordered by an exceptionally resistant series of tilted sandstones, almost deserving of the name of quartzites, which form the "Flat-irons" south of Boulder, Plate $\nabla b$, with summits higher than the neighboring highland peneplain. Here the mouth of the gorge is $\mathrm{Y}$-like, the upper part presumably indicating an approach to a mature form, corresponding to the broad peneplanation of the Plains, while the lower part is still narrow and young, corresponding to the episodes of valley excavation in the Plains. Let it be at once added that the cause of these episodes of valley excavation in the Plains is not necessarily to be sought in renewed regional uplifts. The distance to the sea is so great that a very slight decrease in the slope of the graded rivers across the Plains, such as climatic change might produce, could easily, as Johnson ${ }^{6}$ has pointed out, suffice to account for the observed revival of erosion.

Glacial Sculpture of the Higher Mocxtaixs and Valleys.The subject here reached is one in regard to which there is still some difference of opinion among geographers and geologists; hence it would be now appropriate to resort to an analytical method of presentation, in order to determine whether the temporary occupation of the valley heads among the higher monadnocks by local glaciers was competent or not to produce the peculiar forms which are there so mani-

\footnotetext{
${ }^{\circ}$ W. D. Johnson, The High Plains and Their Utilization, 21 st Ann. Rep. U. S.
} Geol. Surv., Part IV, 1901, 601-768. See page 628. 
festly unlike those of the non-glaciated valleys. But those who have become convinced that glaciers are remarkably effective agencies of mountain sculpture may be excused if they do not, on each return to a formerly glaciated mountain range, return also to a statement of the reasons that have led them to regard the highly peculiar forms there occurring as due to glacial erosion.

For my own part, my previous essays have said all that I have to say, for the present, upon the analytical aspect of the subject; and as the features of the higher parts of the Front Range, seen last summer, brought only abundant confirmations of conclusions reached previously and elsewhere, it appears fitting to continue here the regional treatment adopted on the previous pages. I shall, however, occasionally relapse into a somewhat systematic treatment of glacial features, because the employment of such terms as young, mature and old in connection with forms of glacial origin is not yet generally established.

The first point to emphasize in this connection is the three-fold order of statement that is necessary, if one would adopt a thoroughgoing explanatory treatment for the description of glaciated mountains. A clear understanding of this problem can be gained only by stating, first, in terms of structure, process and stage, the general character of mountain form that was attained in immediately pre-glacial time; second, the amount of work done during the episode of glaciation, both directly by eroding the parts under the ice, and indirectly by sapping the parts above the ice, as well as by deposition of moraines; and third, the work done by normal erosion in postglacial time.

A three-fold order of statement of this kind is, however, not peculiar to the physiographical account of glacial erosion; it is needed wherever existing physiographical forms result from discontinuous processes. For example, in the treatment of the simplest of all kinds of forms, a coastal plain, it is necessary to state first, the form of the sea bottom before uplift; second, the amount and character of the uplift whereby a part of the sea bottom was raised into a land surface; and third, the changes that have since then been introduced by normal and marine erosion. Or in the case of an interruption of a cycle by movement of the land mass with respect to baselevel; it is here necessary to state, first, the form that the region had assumed before the interruption occurred, and this statement can be best made, as usual, in terms of structure, process, and stage; second, the nature and amount of the movement causing the interruption; and third, the erosional work done in the new cycle that was introduced by the interrupting movement.

So in the geographical treatment of a fault, which is simply a special case of the preceding more general case: first, the form of the 
district before faulting took place; second, the nature and amount of the faulting, including here the length of the fault, the height of its escarpment at different points along its course, and the relative displacement of the adjoining blocks; and third, the changes due to erosion since faulting. Again, for shore lines; it is essential to state, first, the form that the region had gained before the movement took place by which the land mass was placed in a new attitude with respect to the ocean; second, the nature and amount of this movement, from which the features of the initial shore lines may be stated as a corollary; third, the changes that have been produced by marine and normal agencies since the movement. In all these cases, the importance of the first statement decreases if the forms that it describes are practically obliterated by the changes under the second and third statements; and a twofold order then suffices.

In view of the demonstrated complexity of the glacial period in the Rocky Mountains and its division into at least two glacial epochs, separated by an interglacial epoch of a considerable duration, as appears from studies by Ball, Westgate, Capps and other observ. ers, it would appear to be theoretically necessary here to expand the threefold statement into a fivefold statement; but as far as our observations in the Front Range-and also in the Sawatch Range, west of the upper Arkansas Valley-are concerned, the subdivision of the glacial period into successire epochs is here a geological problem of little geographical import. It seems as if the glaciers of the later epoch merely went on with the work of the earlier glaciers; hence the net geographical consequences of glaciation are much the same as if the two separate epochs had been consolidated into one longer epoch. Closer study may, however, require a change in this simple statement of the case for the Rocky Mountains, as it has already for the Alps. It may be noted in passing that the Rocky Mountain region affords no sufficient evidence in support of the view that glacial episodes were brought on by an elevation of the region, and interglacial episodes by a depression.

The preglacial form of the Front Range highlands and monsdnocks may be inferred from the description already given of their present form. The monadnocks must then have been somewhat higher, and the normal valleys shallower and narrower than they are now; but the general quality of form must have been much the same as at present. The higher part of the range must have been then, as now, an up-arched peneplain, surmounted by irregularly scattered subdued monadnocks, usually of large-bodied, coarse-textured, waste-covered form, rising from five hundred to twenty-five hundred feet over the highland, and but slightly incised by their wide-spaced valley heads. True, the more massive granites rose in craggy outlines, but these are 
not now to be considered, as all the more characteristic features of glacial sculpture that we saw were associated with subdued, wastecovered domes.

Well developed cirques may be counted by the score. The varying relations of domes and cirques are well illustrated in the northern part of the Sawatch Range, as in Figs. D4 and D5. Some of the cirques are small and consume only the lesser part of a dome, as in Plate IIIb; others are huge excavations, leaving only the smaller part of a dome, as in Plate IVa. Evidently, the work done by the valleyhead glaciers must have been a function of their duration, as well as of their size and slope; hence cirques, like any other forms, ought to be treated with intentional regard for the stage of development that they have reached; a point that has lately been emphasized by Hobbs'. It may be noted that the term "glacial cycle," as used by Hobbs, refers to what is here treated as a climatic accident or episode, introduced and closed by a change of climate due to external causes. The phrase glacial cycle, is here reserved for the ideal case of so long a continuance of glaciation under fixed climatic conditions-except for changes of climate with change of altitude due to degradation-that glacial erosion would be carried to its completion, truncating all the higher mountains at the snow line, and thereby causing snowfall to be replaced by rainfall, and glacial erosion by normal erosion, in a manner shown in Fig. 3, and long ago conceived by the active imagination of Tyndall, but by him erroneously applied to the actual case of the Alps.

The largest, steepest and longest-lasting glaciers naturally had their sources in the highest valley heads among the loftiest monadnocks of the range crest; particularly in valley heads on northern slopes, where the effect of sunshine was least, and in valley heads on eastern slopes, where the snow accumulated by drifting over the rounded mountains during westerly gales. The wind appears, as one may judge by the strong development of east-facing cirques, to have been a stronger cause of asymmetry than the inequality of sunshine; and this need surprise no one who observes the strong effect exerted by the west winds today upon the growth of vegetation on the higher western slopes. Systematic asymmetry of this kind has been pointed out in the Sierra Nevada by Gilbert. ${ }^{8}$

The transformation of a normal valley into a mature glacial trough must also be a work of time; hence conscious attention should be given to the different stages of development in which troughs were left when their glaciers melted away. In enlarging a submature,

\footnotetext{
${ }^{7}$ W. H. Hobbs, The Cycle of Mountain Glaciation. Geogr. Journ., 1910, 146-163, 268-284.

- G. K. Gilbert, Systematic Asymmetry of Crest Lines on the High Sierras of California. Journ. Geol., XII, 1904, 579-588.
} 
$\nabla$-shaped, normal valley, into a mature, round bottomed, overdeepened trough with oversteepened sides, there must necessarily have been successive stages of progress; and if glaciation had been suspended at a halfway stage, an unfinished trough would have been revealed, with many unconsumed spurs, large knobs and hummocks of rock on its sides, and repeated steps and basins in its floor, the latter often being the result of slight differences in rock resistance determined by variation in the number and attitude of joints and other fissures, as well as by changes of composition. Hence troughs as well as cirques should be described in terms of the stage of advance reached by glacial action when the glacial episode was terminated.

The work of postglacial time is small. The basal slopes of the steeper walls in the cirques and troughs are coming to be cluttered with talus, which is creeping forward on the rock floors. "Chimners" are often opened on lines of weakness in the cirque walls. The tarns in the cirques are usually reduced in size by a fan or delta; the smaller basins and depressions in the trough floors are commonly concealed beneath aggraded waste. But all these changes are of small volume; glacial sculpture still dominates the form where the glaciers worked.

Domes, Cirques and Trocghs. -By good fortune, as far as the manifest exhibition of glacial erosion is concerned, the transformation of normal valley heads into cirques did not usually advance so far as to destroy all traces of the normal monad-

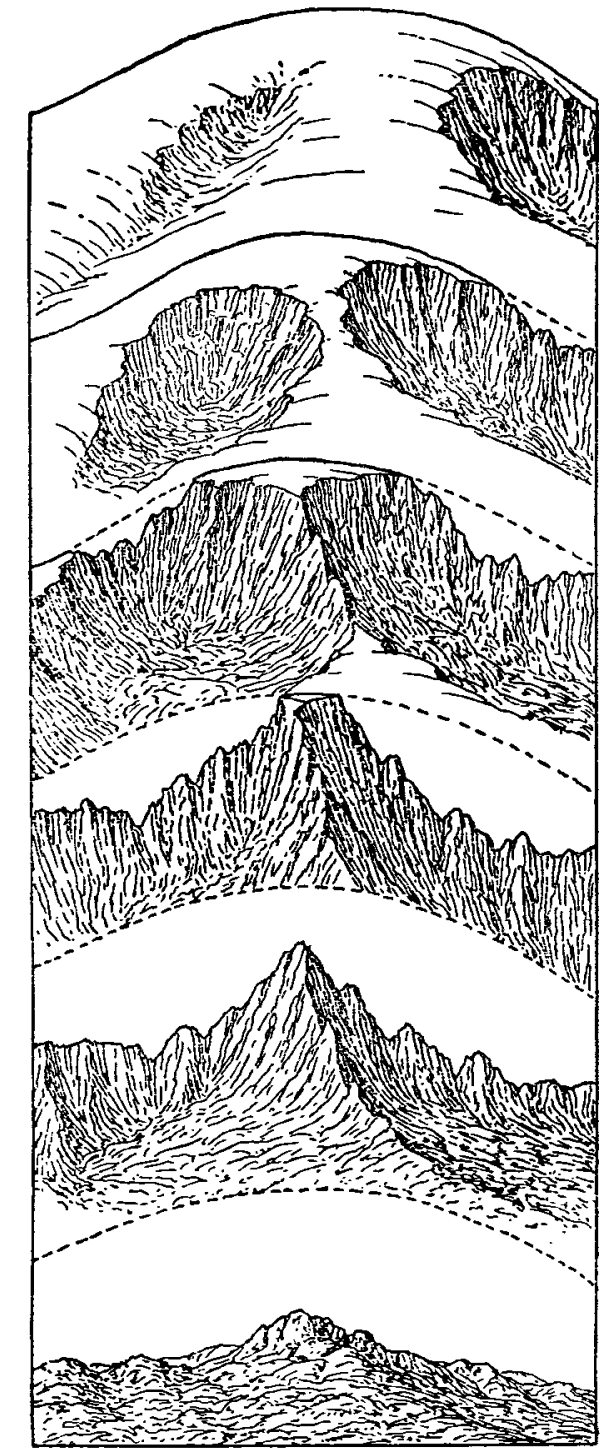

Fro. 3.-Successive stages in the symmetrical development of eirques in a domed mountain. 
nock domes; hence the combination of normal and of glacial forms is most striking. By equally good fortune, the change in some cases was so great that no remnant of the dome summit is now seen; the retrogression and lateral enlargement of the glacial heads went on in these cases so far as to change the full-bodied dome into a sharpened peak, with deep, hollow-chested cirques between serrate spurs,

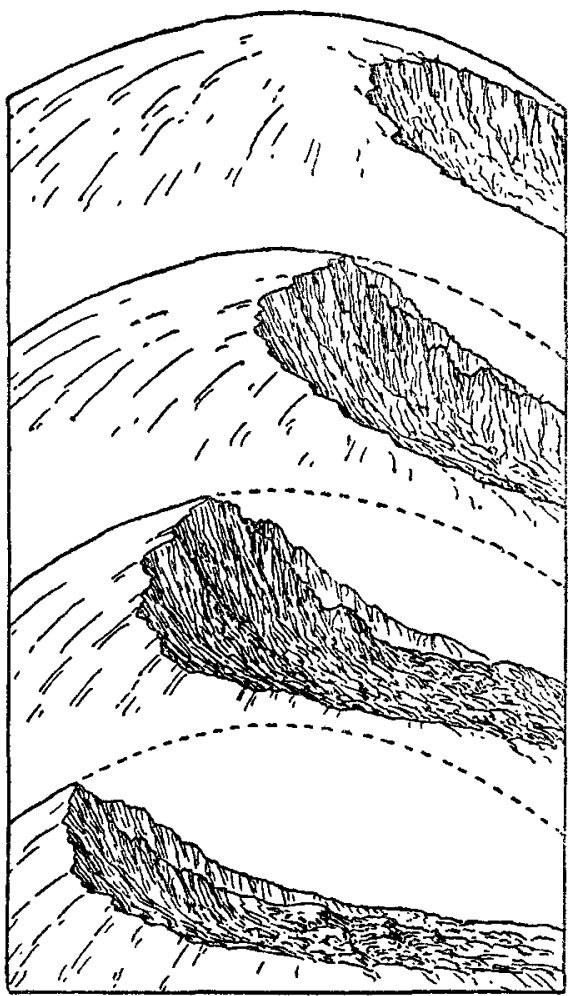

Fig. 4.-Successive stages in the unsymmetrical development of cirques. leaving normal forms only on the lower flanks of the dome between the diverging glacial troughs.

By selecting examples of actual forms, or by induction, as in Fig. 3, one may establish a regular sequence of changes from small cirques, between which the greater part of a dome is intact, to large cirques between which no part of a dome is seen; or if analysis and historical review are added to induction, and full confidence is thus established in the explanation of cirques by glacial excavation, one may form an even more complete and systematic series of glacial forms, filling the gaps in the inductive series by appropriate deduction. The use of deduction makes it possible to extend the series farther than observation can reach in the mountains of Colorado, even to the point of consuming the central peak by convergent retrogression of several glaciers, as Richter suggested twelve years ago, thus truncating the dome at about the level of the snow line. Retrogressive truncation may be symmetrically accomplished from all sides, as in Fig. 3; or unsymmetrically from one side only, as in Fig. 4. When a systematic series of forms of this kind is well understood and the names of its several members-for example, young, mature and oldare familiarly established, they are ready for effective use in regional description: thus the progress through several phases of preparatory study-observation, induction, analysis, review, systematization-and 
their application in the culminating regional phase are well illustrated in treating forms of glacial origin, as well as forms of other kinds.

As an example of the way, indicated above, in which deduction may outstrip induction in the establishment of a systematic series of forms, which follows in general a main line of sequence, but which branches here and there, as desired, on side lines, brief mention may be made of the contrasted consequences of retrogressive erosion by glaciers of divergent and of convergent flow, as illustrated in the fancy sketch, Fig. 5. The maturely retrograded cirques of the divergent glaciers, $A, B, C, D$, would be expected to head against a single lofty, sharpened peak; their back walls should be separated by short spurs, and their inner floors should be nearly confluent; while their forward parts, separated by spurs of increasing size and normal form, ought to open into

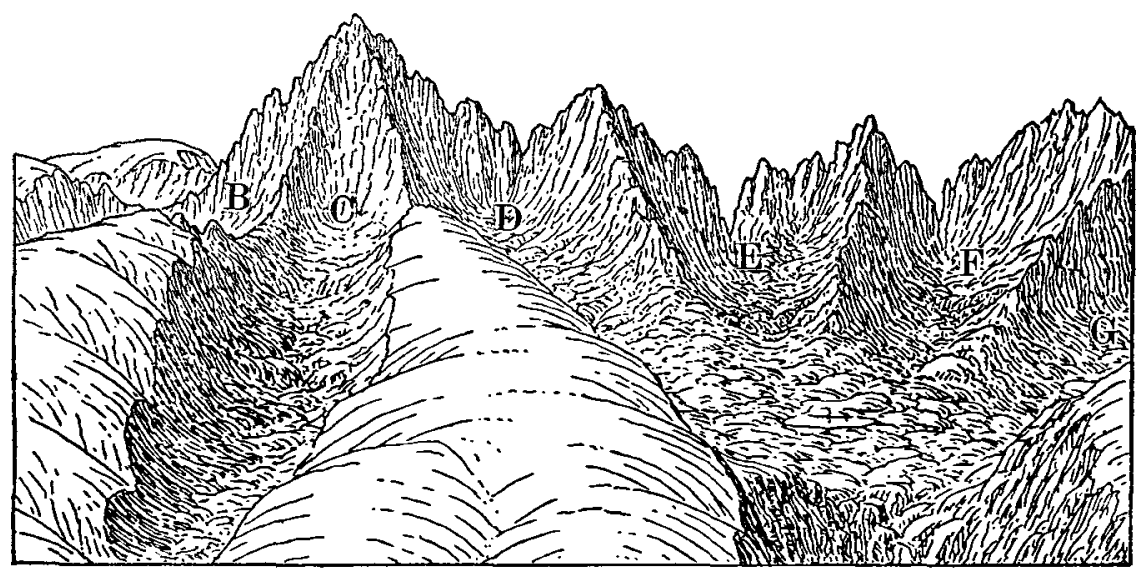

Fra. 5.--Divergent and convergent cirques.

independent troughs of moderate depth. The corresponding cirques of the convergent glaciers, D, E, F, G, heading against deeply notched peaks and ridges, ought to be separated by longer spurs, and to become confluent in their forward floors, just above the head of the strongly over-deepened trough into which they all discharge. This is very likely well known to Alpinists, but $I$ have not seen it concisely stated; it goes beyond my own experience, and as here presented is essentially a matter of inference. Until confirmed by observation, it ought to be regarded as a matter of fancy, not of fact; but even so it may have value in leading to observation and in hastening recognition.

Cirques axd Troughs at the Head of the Boulder Creeks.The best cirques that we saw in the Front Range were at the heads of the branches of the Boulder Creeks. They are easily visited by walking a few miles north and south along the crest of the Continental Divide from Corona station on the "Moffat" railroad, except 
that accommodations for staying there over-night are very poor. The most striking feature is the strong asymmetry of the crest ridge, Fig. $\mathrm{B} 2$, which on the west shows the slopes of confluent, low monadnocks, well subdued in graceful, convex form, waste covered and overgrown with Alpine herbage; but on the east shows deeply excavated, concave cirques with bare rocky walls and barren, moraine-strewn floors, often holding small lakes. Hence these domes and cirques should be described in terms of such a series as is illustrated in Fig. 4, instead of in Fig. 3. The gradual transformation of a broad-topped dome into a serrated ridge between two encroaching cirques of the Middle Boulder group, directly under A, Fig. B2, is shown in Fig. 6. Many of the cirques are compound, in the sense of having small cirques at a higher level opening into larger cirques at a lower level. Some fifteen tarns in the cirque floors in this district are given altitudes

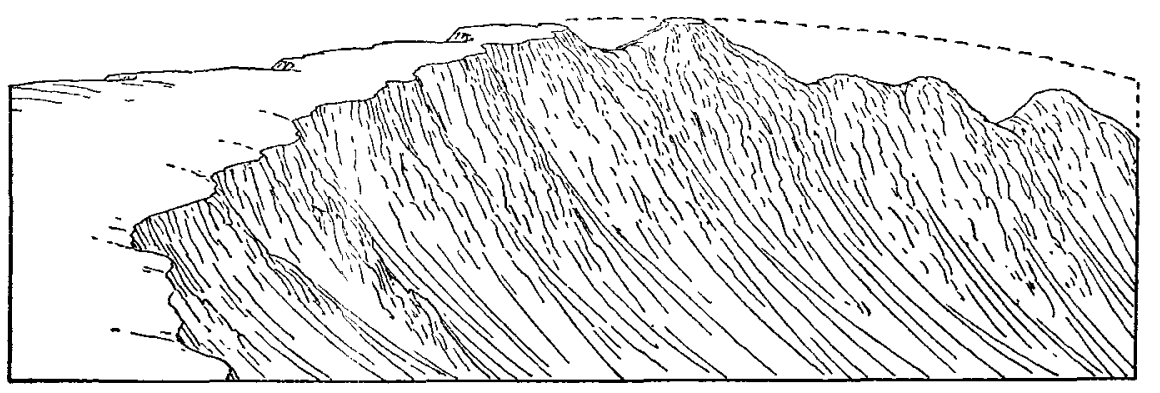

Fig. 6.-Transformation of a broad dome into a sharp ridge, by glacial erosion.

varying between 10,450 and 11,370 feet on the Central City map, U. S. Geological Survey. In a number of cases, as in Fig. B2, the head walls of several laterally confluent, mature cirques have been pushed back beyond the erest of the preglacial domes, so that the Atlantic drainage has gained a little over the Pacific drainage. A few miles to the south, James Peak (13,283 feet), a most interesting example, shows a remnant of a dome crest, Fig. E2 and Pl. IVb, with a grassy slope to the north, and huge submature cirques on the west and east; the map of the district indicates a third cirque on the south side. Somewhat farther away to the north, Arapahoe Peak $(13,520$ feet,) outlined in the background of Fig. B2, is more consumed; its serrated crest has no trace of dome form; a large cirque on its eastern side contains one of the few glaciers in Colorado, of which Lee and Fenneman have given account. ${ }^{9}$ Hence, according to a system-

\footnotetext{
${ }^{\circ}$ W. T. Lee, The Glacier of Mt. Arapahoe, Colorado. Journ. Geol., VIII, 1900, 647-654.

N. M. Fenneman, The Arapahoe Glacier in 1902, Ibid., X. 1902, 839-851.
} 
atic scheme, the lower monadnocks near Corona would be described as half or more than half consumed by mature cirques on the eastern side; James Peak as a small remnant of a high dome, encroached on by nearly mature cirques on three sides, but retaining a normal slope on the north; Arapahoe as converted to somewhat Alpine sharpness by the excavation of late mature cirques on all sides.

Several well matured troughs lead eastward from the cirques of the Boulder district. One that is drained by the South Fork of Middle Boulder Creek has its group of convergent mature cirques at several levels next north of Corona, partly shown at MI, Fig. B2. The view down the trough into which these cirques discharge, as seen from the top of one of the cirque walls, Fig. E3, shows it to be maturely developed with a catenary cross-section, for the description of which the term $\mathrm{U}$-shaped is altogether inappropriate. Its course is of long and gentle curvature, its floor is nowhere entered by well defined lateral spurs. The train on the Moffat road, on approaching the range crest, runs for part of a mile in a cornice along the upper part of the high southern wall of the trough, whence, if one is not nervous, one enjoys an exceptionally fine view of the blunt trough head and of the stream that cascades down into it fron the lowest cirque floor. About three, and four and a half miles from its head, this trough is joined on the north by the similar troughs of Jasper Creek and North Fork, which come from a fine group of submature and mature cirques, deeply carred in the crest of the range. The village of Eldora, reached by a narrow gauge line from Boulder, is farther down the main trough. Judging by the height at which boulders are perched on the trough sides, the ice must have been a thousand feet thick there. Lateral moraines are suspected high on the south side of the trough and are probably the cause of two little lakes, shown on the Central City map. The moraines seem to descend to lower and lower levels eastward, but were nowhere seen of great size. About eleven miles eastward from the cirques above the trongh heads, the open trough, in which the Middle Boulder glaciers united, narrows and ends at an altitude of 8,200 feet, and is continued by the normal submature gorge of Middle Boulder Creek.

The group of mature or late mature cirques excavated in the eastern slope of the range crest next southward from Corona station, some of which are shown in the foreground of Fig. B2, discharge into the deep and mature trough of South Boulder glacier; the trough narrows and ends at an altitude of 8,000 feet, without any well defined terminal moraines, about eight miles from its head, and is continued by the normal valley of South Boulder Creek, which soon becomes a steep-sided submature, $\nabla$-shaped gorge of decidedly irregular course, as in Fig. A3. The distal part of this trough is aggraded 
and partly occupied by a marshy meadow, partly by low drift hills and terraces; it is called Boulder Park, and is occupied by the village of Tolland. The trough deserves, on the whole, to be described as mature, but there are several good-sized unconsumed rocky knobs on its sides and floor. Its walls truncate several spurs in triangular facets, and leave the ravines between the spurs hanging high above the trough floor and partly inclosed by lateral moraines. A large branch trough, known as Mammoth Gulch, heading in the eastern cirque of James Peak, Fig. E2, comes from the southwest and opens several hundred feet above the main trough; many well defined moraines occupy this hanging trough near its mouth. The Moffat road passes through Boulder Park and then returns on its northern wall in a double loop, Fig. C6; the unweathered rock in the cuts on the side of the glaciated trough, and the deeply weathered rock waste, in cuts outside of the limit of glacial action, are strikingly contrasted. A remarkably fine mature trough on the western side of the Sawatch Range is shown in Plate $\mathrm{Va}$.

The absence of large terminal moraines in the distal part of the Boulder troughs is significant of the thorough work of the glaciers in comminuting the eroded rock so finely that nearly all of it could be carried away by the outflowing streams. The moraines represent only a very small fraction of the excavated material; perhaps about a hundredth part. On the other hand, the glaciers that descended from the Sawatch Range eastward into the open intermont basin of the upper Arkansas Valley, formed terminal moraines of great size, three pairs of which are beautifully illustrated in drawings by Holmes in one of Hayden's reports.

The Trough of Clear Creer.-The mature trough of the Clear Creek glacier in the Georgetown district presents several features of interest. The main trough, trending north-northeast, divides at its (southern) head into two subequal branches; one (that of South Clear Creek) from the south, the other (that of Clear Creek) from the westh; each of these hangs above the main trough floor, and in the mouth of each of them a connecting gorge is cut, thus exemplifying the rule announced by Penck and Brückner as to the greater depth of a main trough, formed by the junction of two equal branches. These hanging trough mouths were explained some years ago by $\mathrm{Crosby}^{10}$ as the result of a fault; but as no indications of a fault scarp are to be seen on the slopes of the inclosing mountains, and as it would be singular that a fault should cut two tributary troughs just where they unite to form a main trough, and displace them so as to produce typical "hanging" relations, the explanation by

${ }^{10} \mathrm{~W}$. O. Crosby, The Hanging Valleys of Georgetown, Colorado. Amer. Geol., XXIII, 1903, 42-48. 
unequal glacial erosion seems preferable. Georgetown lies at the upper end of the main trough floor. The narrow gauge railroad from Denver continues up the western branch trough to the village of Silver Plume, and in order to make the necessary ascent at the hanging mouth of the branch trough, the track turns on itself in the famous "loop." A heavy landslide from the south wall is passed just above the "loop"; it seems to have formed a lake, now aggraded into a meadow, on which Silver Plume lies near a large, unconsumed rock knob of the north wall. From here a mountain railway ascends the south side of the trough in a series of switch backs, and turns around the promontory that divides the two branch troughs, thus disclosing fine views into both of them and down the main trough; . then slants up the northern wall of Leavenworth Gulch, a hanging southwestern branch of the southern trough, for a dozen miles, and finally zigzags up the normal eastern slope of Mt. McClelland $(13,423$ feet), from the top of which, Fig. 7, the visitor has a

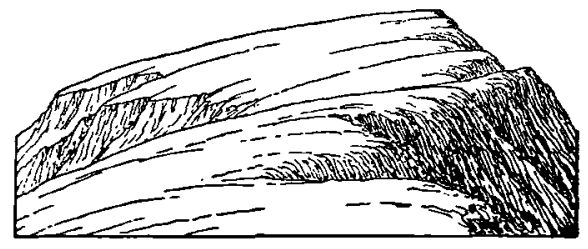

Fig. 7.-Mt. MeClelland, an unsymmetrically consumed dome.

grand sight of the great cirques on the northeastern side of the double Grays (13,341 feet) and Torreys (14,336 feet) mass, Fig. E1. The walls and floors of these cirques are much encumbered with slide rock. The northern spur of Mt. McClelland, Fig. D3, is exceptional in having a steeper rocky slope on the west, and a less steep graded slope on the east; this is because the western side was undercut and steepened in the deepening of the glacial trough from Grays and Torreys Peaks. A small cirque seen to the north, across Clear Creek trough, is shown in Fig. D2.

Mt. Evans $(14,330$ feet) is a striking feature of the view to the southeast from Mrt. McClelland. It was evidently once a full-bodied, complex dome, but it is now a hollow-chested wreck, greatly consumed by seven huge cirques, of which one opens to the west, and one to the north; its form is suggestively indicated by the contours of the Georgetown, Colo., topographical map. It is worth noting that a small side valley hangs high on the south side of Leavenworth Gulch, which hangs over South Clear Creek trough, and this in turn over the main Clear Creek trough, thus making a four-storied succession. 
Below Georgetown the main trough, trending northeast, is remarkably well developed; the walls are somewhat ragged, yet simple and spurless; many small side valleys hang high above its floor; connecting ravines are slightly cut below the hanging valleys, and fans are spread in the main trough; but all these features weaken ten miles below Georgetown, after the trough turns eastward, where it seems to end at an altitude of 7,900 feet; here the creek flows in a narrow valley of normal appearance, soon to be joined by the more trough-like valley of Fall River, which comes from the northwest, heading in the southern cirques of James Peak. The combined waters, still called Clear Creek, flow eastward and have an open, trough-like valley for some five miles below their junction, and here the town of Idaho Springs is situated. To my surprise Ball's description and the geological folio of the Georgetown district do not indicate that this trough-like valley has been glaciated, although the view of it from a passing train strongly suggested a glaciated form. If glaciated, its ice probably came from James Peak, ten or twelve miles distant.

The Mountain Border.-What will be the appearance of the border of a mountain mass, in which the fundamental crystalline mass has suffered planation before a heavy series of weaker sedimentary strata was deposited upon it, and in which the compound mass was then divided by a pronounced north-south monoclinal displacement into a higher western area (the Mountains area) and a lower eastern area (the Plains area); then worn down to a peneplain which crossed from the crystalline rocks west of the monocline to the stratified rocks east of it; then uplifted long enough ago for the weaker rocks to be again peneplained while the harder rocks are only submaturely dissected?

Such a mountain border must be as rectilinear as the monocline that it follows, and almost as steep as the dip of the monocline; it must consist of a series of triangular or trapezoidal facets all standing in line, but separated by the notches of many superposed consequent valleys and ravines; somewhat the worse for wear near the top, somewhat protected by overlapping members of the stratified series near the base; its height not at all dependent on the much greater height of the monocline, but on the amount of the last uplift and on the resultant depth to which the weaker strata of the plains are now removed. Such a mountain border is in fact a fragment of a huge inorganic fossil, an ancient surface of planation, long preserved by being buried under later deposits, after the manner of organic fossils; then uplifted, attacked by erosion, its upper part destroyed, its middle part laid bare, its lower part still remaining 
buried. Its smoothness in the Boulder district is emphasized by Fenneman. ${ }^{11}$

Where the basal covering strata are unusually resistant, they hold fast to the old planation surface, as in the remarkable "Flatirons," shown in Plate Vb, between North and South Boulder Creeks, suggesting the type shown in the farther part of the front block of Fig. 1. Where a resistant formation occurs a thousand or more feet up in the covering strata, it will now rise as a subsequent monoclinal ridge a half a mile or a mile forward from the mountain base, notched here and there into " hogback" form by the larger consequent streams, and inclosing a series of subsequent rallers, along which the smaller consequent streams from the mountains will be diverted by subsequents until they join the larger consequents and flow out by the notches, as shown in the nearer part of the front block of Fig. 1. Many excellent illustrations of the outstanding ridges are reproduced in Holmes' inimitable drawings in the earlier reports of Hayden's Survey. Where the covering strata are all weak, there will be neither clinging "flatirons" nor outstanding "hogbacks," a new peneplain will truncate all the monoclinal strata forward from the uncovered planation surface of the mountain border, as happens along the Front Range border for a short distance south of Palmer Lake, north of Golden, and at various other points.

The embayments of the mountain front at Manitou and Canyon City, already mentioned in connection with the subdivision of the highland into several districts, deserve more space than can be given them in this already over-long essay. They are significant as exhibiting in part of their contour the replacement of the monocline by an oblique fault, trending northwest-southeast; here the foothill subsequent ridges, instead of systematically following the mountain base at a rather constant distance, run obliquely against it and are truncated by the fault line. This is particularly well seen in the Manitou embayment, where the many and well developed subsequent ridges of red sandstone, which in the district of their strongest expression form the "Garden of the Gods," a mile or two farther south abut against the base of the Pikes Peak highland and end abruptly. A view of this significant relation is given in one of Holmes' drawings (Hayden's Surrev, Report for 1873, 1874, 200). Both embayments are mapped in Darton's account of the Arkansas Valley. ${ }^{12}$ The

\footnotetext{
${ }^{11}$ N. M. Fenneman, Geology of the Boulder District, Colorado. Bull. 265, U. S. Geol. Surv., 1905, p. 54.

${ }^{12}$ N. H. Darton, Geology and Underground Waters of the Arkansas Valley in Eastern Colorado. Prof. Paper 52, U. S. Geol. Surv., Washington, 1906.
} 
ancient surface of planation near Manitou has been well described by Crosby. ${ }^{13}$

The tilted attitude of the strata near the mountains immediately gives the impression that the mountains owe their height above the plains to the monoclinal uplift by which the tilting was produced; but as soon as the peneplain of the highland is recognized in its proper relation to the mountain front, this first impression must be given up. The height gained by monoclinal tilting has been lost by peneplanation; since then, both the mountains and the plains have been broadly uplifted, the mountains a little more than the plains; and the present difference of altitude along the border of the range is due simply to the erosion that the weaker strata of the plains have suffered, whereby they have been much more worn down than the part of the uplifted peneplain that is composed of harder rocks.

Marvine's EarLy Work on the Front Range.-It was this mountain front, so striking and typical an example of its kind, which first suggested the idea of superposed consequent drainage; for here Marvine, returning in 1873 as a member of Hayden's Survey to the scene of Whitney's excursion of 1869, wrote: "The channels of drainage ... [on the border of the Front Range] were directed solely by the structure and characters of the upper rocks, and when they gradually cut down through these and commenced sinking their cañons into the underlying complicated rocks, these cañons bore no relation whatever to their complications. . . . Penetrating the formerly covering sedimentaries, the cañons commenced sinking into the lower and more complicated rocks, with directions impressed upon them by the latest uplift and the overlying rocks, and bearing no constant relation to the structure of the lower ones in which we now find them . . . in a broad sense, the drainage is from the main mountain crest eastward, independent of structure. . . The subaqueous erosion, in smoothing all to a common level, destroys all former surface expression of geological character, and the present erosion has not yet been in progress sufficiently long to recreate the lost features." 14 Powell afterwards referred to this passage when he introduced the terms, consequent and superimposed, the latter term afterwards being shortened into superposed.

It was in relation to the ancient planation surface of the mountain front that Marvine, first of all observers, published the idea of the essential obliteration of mountains and hills by normal erosion, although he, like others of his time, seems to have looked to marine abrasion

\footnotetext{
${ }^{13}$ W. O. Crosby, Archaean-Cambrian Contact near Manitou, Colorado. Bull. Geol. Soc. Am., X, 1899, 141-164.

1t A. R. Marvine, Report in Ann. Rept. of the U. S. Geol. and Geogr. Survey Terr., Washington, 1874 , p. 145.
} 
as the agency by which the final planation was produced. He wrote: "The ancient erosion gradually wore down the mass to the surface of the sea, and while previous to this it [erosion] was no doubt directed by the structure, yet the mass was finally levelled off irrespective of structure or relative hardness of its beds by the encroaching ocean, which worked over its ruins and laid them down upon the smoothed surface in the form of the Triassic and other beds" (l. c., 144). Although the first line quoted gires hardly more than a hint of a great principle, it is significant that subaerial erosion was there recognized as capable of wearing down a mass of deformed crystalline rocks "to the surface of the sea," and not simply into hills and valleys, as was thought and taught at that time.

In common with other observers, Marvine recognized the evenness of the Front Range highlands, but he went beyond his contemporaries in trying to explain it. He described the highlands as " a region of pine-sprinkled surfaces . . . . large areas are frequently undulating or level, forming beautiful park-like regions . . . . there is a remarkable uniformity in the height of these ridges. Their tops are frequently quite level or gently rounded; while standing on one, the general level, which seems indicated in their tops, is very striking" (1. c., 89). In explanation of this feature, he looked back to the same planation surface as that recognized in the even front of the range; no one at that time conceired the peneplanation of the highland surface as having taken place in a cycle of erosion following instead of preceding the monoclinal deformation of the compound mass. Marvine's statement was: "It is but recently that the upper rocks have been completely removed from the summits of the mountain spurs, the ancient level of subaqueous erosion being still indicated by the often uniform level of the spurs and hilltops over considerable areas, and large plateau-like regions which become very marked from certain points of view" (l. c., 145). The important point to note here is that Marvine had formed a mental scheme by which an intelligible understanding of the forms of the Front Range could be worked out. True, we must now regard his scheme as erroneous in certain respects; nevertheless, the effort to give rational explanation for all the forms of the mountainous highlands was a great step in advance of the methods of his time. That a young geologist - Marvine was then twenty-five years of age-should in 1873 have already so fully accepted the responsibility of explaining the forms of the surface, as well as the structures of the undermass, reveals the originality and analytical power of his mind, as well as the keenness of his observation.

Opinions regarding glacial erosion were undefined forty years ago. Rock scorings and moraines are repeatedly mentioned in the reports 
of the Hayden Survey, but it is seldom that cirques and troughs are treated as being due to other than ordinary erosional processes. If glacial erosion was considered at all, it was as likely as not given an extravagant measure, as when Hayden said, regarding the intermont basin of the upper Arkansas Valley: "It is probable, also, that this great space was at no very ancient period filled with one vast glacier, which doubtless performed the greater part of the grinding up of the rocks and the wearing out of the valley" (1. c., 48; also $1876,51)$; yet the same writer, after clearly recognizing the great amphitheaters or cirques as characteristic features of the higher moun. tains, seems to explain them by a "gnawing process, as it might be called," which has "been going on for ages, so that in many places the crest is a single sharp ridge between the amphitheaters on either side." Each mountain stream "rises in a sort of amphitheater, which has been formed by the breaking down of the sides of the gorges by the water and ice in the fissure, and the melting of the snow sweeps the fragments slowly down into the gulch" $(1875,44)$. "That the wearing out of the depressions [amphitheaters] may have been more rapid in former times, I do not doubt, perhaps during glacial or post-glacial times" $(1875,45)$. "Although the evidence is clear that these amphitheaters have been carved out of the massive granite, no forces are now in operation to carry away the fragments of rock that are annually loosened from the walls by water and ice, but they gather on the slope, forming a talus of great magnitude" (1875.56).

The unsymmetrical crest of the range in the Boulder district, sketched in Fig. B2, attracted the attention of more than one member of Hayden's Survey. Marvine says of it: "From Arapahoe, for twelve miles directly south to James Peak . . . the crest presents a very uniform ridge rising but little above timber line, and for five miles near the southern portion scarcely varying two hundred feet in altitude. As at the north, the eastern face of this ridge is precipitous, falling in great cliffs to a series of amphitheaters which make up the front, each with its bank of snow lying up against the base of its rocky walls. Some of the rounded spurs reaching eastward between the amphitheaters, afford a means of access to the ridge. - . The western slope from this ridge is of a very different character from the eastern slope. Though of course having many of the characteristics of a rugged, mountainous region, yet, as compared with the east slope, it has no precipitous front, but its massive westward spurs fall in rounded, gently moulded slopes, not separated by deep cañons" (1. c., 86, 87). The only explicit statements that $I$ have found in his report regarding glacial erosion are contained in the quotation at the beginning of this paper, and in the 
following lines: "Starting from the eastern base of Gray's and Torrey's Peaks [see Fig. E1 in this paper], and curving around northward, is a most profound and regular glacier-carved gorge, with sweeping, precipitous sides towering up on the east side to the rather even-topped summit [see Fig. 7 of this paper] of McClellan Ridge" (1. c., 148).

The report from which the extracts here given are quoted, is one of the few that Marvine produced. Hayden wrote of it: "The energy and devotion to the work displared by Mr. Marvine merit the highest commendation, and the results so admirably brought out in his report . . . are but promise of the future" (l. c., 4): a future that was most unhappily cut short by his death in 1876 .

The Probiem of Intersecting Peneplains.--Physicists have found it desirable to give the special name, entropy, to a certain

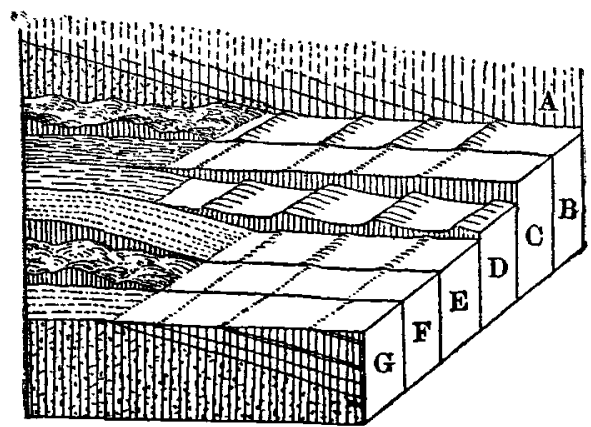

FIG. 8.-Intersecting peneplains.

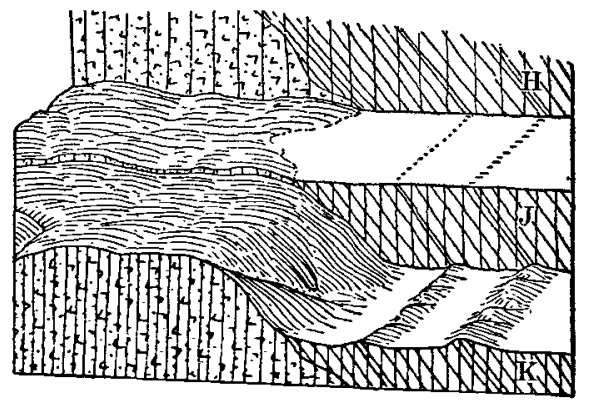

FIG. 9.-Peneplains intersecting at a large angle.

involved conception, because they so often have occasion to refer to it; thus they avoid much circumlocution. Physiographers have not yet given a special name to the combination of several peneplains, as seen in the highlands and the front of the Front Range, and in the piedmont plains, although one phase or another of such a combination is a common occurrence, and a name for it would frequently be useful. One of my students has suggested that the combination should be spoken of as that of "intersecting peneplains." Their varying relations are shown in Fig. 8 . The essential element of structure is a compound mass, consisting of resistant rocks below, and of less resistant rocks above, separated by a surface of unconformity, the double mass being tilted, as in section $A$. The chief variable elements of structure are the contrast of resistance between the lower and upper rocks, and the smoothness and inclination of the surface of unconformity. Contrasted resistance and a smooth surface of unconformity inclined about $30^{\circ}$ are represented in this figure. The essential elements of later erosion are an approximate or perfect planation 
of the tilted compound mass, as in blocks $\mathrm{B}$ and $\mathrm{C}$; the variable elements of later erosion depend in part on the nature and amount of the elevation by which the worn-down mass, $\mathrm{B}$ or $\mathrm{C}$, is introduced into a new cycle of erosion, and on the stage reached in this cycle. After simple uplift of moderate measure, block $\mathrm{D}$ shows a late mature stage of erosion in the weaker strata and a partial stripping of the surface of unconformity; block $\mathrm{E}$ shows a new peneplain worn on the weaker strata, and the complete stripping of the surface of unconformity, while the hard-rock highland remains little changed; block $F$ shows an aged plain on the weak strata and a late mature dissection of the hard-rock highland; block $G$ repeats block C. Fig. 9 is a variation of Fig. 8, showing an uneven surface of unconformity, a steeper tilting of the compound mass, and a greater uplift after truncation. The border of the highland as here developed is uneven, chiefly because the stripped surface of unconformity is uneven. It is evidently possible to conceive a large number of variants on these simple examples.

The object of here introducing the scheme of intersecting peneplains is to point out a better method of presenting the problem of the mountain border than that of the first paragraphs under this heading, six pages back. The particular case of the Front Range border was there entered abruptly, without systematic preparation. This is inadvisable, because the reader then has the actual mountain border and its hypothetical explanation both before him at the same time. It is better to treat the two separately. Let the hypothetical case be taken first, and let its presentation be systematically expanded so as to include various styles and stages of the problem, such as are shown in Figs. 8 and 9. After many variants have thus become familiar, the actual case may be taken up. It then suffices to say: the border of the Front Range corresponds to block D of Fig. 8, except that it is dissected by many superposed consequent ravines and valleys, and that a monoclinal ridge frequently stands in front of it, as is better shown in the front block of Fig. 1.

The Need of Systematic Preparation for Regional Work.This example may serve as a final illustration of the high value of systematic preparation for regional work. The evident difficulty in the way of such preparation is the great variety of land forms and the consequent necessity of elaborate systematic discussion, if the ideal counterparts of all actual forms are to be known before they are seen. But such completeness of preparation is not essential: the point is rather that systematic preparation should be carried much farther than it usually is, if an expert geographer is to gain an equipment that shall at all compare with the equipment that is expected of a proficient botanist or zoologist. If the underlying principle-the principle of first systematically elaborating a good number of variants 
under a hypothetical case, by making reasonable changes in its variable elements, and then stating that the actual example of land form under discussion corresponds to variant $\mathrm{G}$ or $\mathrm{M}$ or $\mathrm{Q}$-is made clear and familiar by preparatory training, it may be applied in special cases, as need arises, even if these cases are not already resolved by previous study. For example, there is no question that the description of the Front Range border could have been briefer and more effective, if the problem of intersecting peneplains were generally recognized and introduced in the systematic treatment of land forms, as presented in our text-books; or again, there can be little question that the subject of this essay, the Front Range of the Rocky Mountains in Colorado, could have been treated more briefly and effectively if the general problem of two-cycle mountains and a good number of its variants were the common property of all geographers; but such is not the case. The question then arises: is it best to open each of these problems with an abstract treatment of their ordinary variant values, or to begin at once by a statement of the case in hand? In view of the fact that this essay was not intended to form part of a systematic course of instruction, but was written as an independent regional treatment of a mountainous district for expert readers, the second method was chosen; but I am by no means persuaded that the choice was well-advised.

The constant inspection of method, here adopted, may be fatiguing to some readers, but in the present stage of the study of land forms inspection of method is highly important. It might well constitute a larger part of the discussions in the meetings of geographical societies than is ordinarily the case. An analogy may illustrate this point. Let it be supposed that in the present stage of the study of mineralogy, every year witnessed the publication of many diverse, inaccurate and inadequate descriptions of new minerals; under such conditions, would it be best for mineralogists to continue to publish inadequate, inaccurate and diverse descriptions of still more new minerals, or to address themselves to the discussion and development of better methods of describing the minerals already imperfectîy known? The latter course would evidently be preferable. A corresponding course is preferable also in geography. For my own part, I should like nothing better than to see abundant, conscious experiments in geographical description; for example, a description of the Front Range: or of some similar range in strictly empirical terms, from which all explanation is excluded; or a description in strictly explanatory terms, but on some other plan than that of structure, process and stage, here adopted. It is by such conscious experimentation and by free discussion of its results that the object of this Association, "the cultivation of the scientific study of geography in all its branches," can be best attained. 


\section{REFERENCES}

S. H. Ball (with J. E. SPURR and S. H. GarreY).

Economic Geology of the Georgetown Quadrangle, Colorado. Prof. Paper 63, U. S. Geol. Surv., Washington, 1908.

E. BLACEWELDER.

Cenozoic History of the Laramie Region, Wyoming. Jour. Geol., Vol XVIr, 1909 ; pp. 429-444.

\section{S. R. CAPPS.}

Pleistocene Geology of the Leadville Quadrangle, Colorado. Bull. 386, U. S. Geol. Surv., Washington, 1909.

W. O. Crosbr.

Archean-Cambrian Contact near Manitou, Colorado. Bull. Geol. Soc. of Amer., Vol. X, 1899; pp. 141-164.

The Hanging Valleys of Georgetown, Colorado. Amer. Geol., Vol. XXIII, 1903; pp. $42-48$.

W. Cross.

Folio 7, Geol. Atlas of the United States. U. S. Geol. Surv., Washington, 1894. N. H. Darton.

Geology and Underground Waters of the Arkansas Valley in Eastern Colorado. Prof. Paper 52, U. S. Geol. Surv., Washington, 1906.

W. M. Davis.

The Geographical Cycle. Geogr. Jour., Vol. XIV, 1899; pp. 481-504.

Complications of the Geographical Cycle. Report of Eighth Internat. Geogr. Congress, Washington, 1905; pp. 150-163.

Glacial Erosion in France, Switzerland and Norway. Proc. of Boston Soc. of Nat. Hist., Vol. XXIX, 1900; pp. 273-322.

Glacial Erosion in the Valley of the Ticino. Appalachia, Vol. IX, 1900; pp. 136-156.

Glaciation of the Sawatch Range, Colorado. Bull. Museum Comp. Zool, Vol. XLIX, 1905; pp. 1-11.

The Sculpture of Mountains by Glaciers. Seot. Geogr. Mag., Vol. XXII, 1906; pp. 76-89.

Glacial Erosion in North Wales. Quar. Jour. Geol. Soc., Vol. LXV, 1909; pp. 281-344.

N. M. Fenneman.

Geology of the Boulder District, Colorado. Bull. 265, U. S. Geol. Surv., Washington, 1905.

The Arapahoe Glacier in 1902. Jour. Geol., Vol. X, 1902; pp. 839-851. H. GannetT.

A Dictionary of Altitudes in the United States. (Third Edition.) U. S. Geol. Surv., Washington, 1899. 
G. K. GIHBERT.

Systematie Asymmetry of Crest Lines in the High Sierras of California. Jour. Geol., Vol. XII, 1904; pp. 579-588.

W. H. Новвs.

The Cycle of Mountain Glaciation. Geogr. Jour., 1910; pp. 146-163, 268-284. W. H. HoLmes.

(Hayden's) Geol. and Geogr. Survey Terr., Report for 1874; Washington, 1875. See plate opp. p. 49.

T. C. Hopkins.

Glacial Erosion in the San Juan Mountains, Colorado. Proc. of Wyoming Hist. and Geol. Soc., Wilkesbarre, Pa., Vol. XI, 1911.

W. D. JoHrson.

The High Plains and Their Ctilization. 21st Ann. Report of U. S. Geol. Surv., Part IV, 1901; pp. 601-768.

A. C. LaWson.

Geomorphogeny of the Upper Kern Basin. Univ. of Calif., Bull. of Dept. of Geol., Vol. III, 1904; pp. 291-376.

W. T. LEE.

The Glacier of Mt. Arapahoe, Colorado. Jour. Geol., Vol. VIII, 1900; pp. 647654.

E. De Martonne.

L'Evolution du Relief de l'Asie Centrale. La Geogr. XXIII, 1911; 39-58.

A. R. Marvine.

Report for the Year 1873. In Ann. Report of the U. S. Geol. and Geogr. Surv. Terr. (Hayden's Survey); Washington, 1874; pp. 83-192.

A. Penck.

Geomorphologische Studien aus der Herzegowina. Zeitschr. deut. u. österr. Alpenver., XXXI, 1900; 25-41. See p. 38.

J. H. Perry.

Geology of the Monadnock Mountain, New Hampshire. Jour. Geol., Vol. XII, 1904 ; pp. 1-14.

E. RICHTER.

Geomorphologische Beobachtungen aus Norwegen. Sitzungsber. Wiener Akad., Math.-Naturw. Kl., CV, 1896; Abt. 1, 152-164.

Geomorphologische Untersuchungen in den Hochalpen. Pet. Mitt., Erg'hft, 132, 1900.

L. G. Westgate.

The Twin Lakes Glaciated Area, Colorado. Jour. Geol., Vol. XIII, 1905; pp. 285-312.

J. D. WhITNEY.

Die Höehste Partie der Felsengebirge. Pet. Mitt., XVII, 1871; 55-56. 


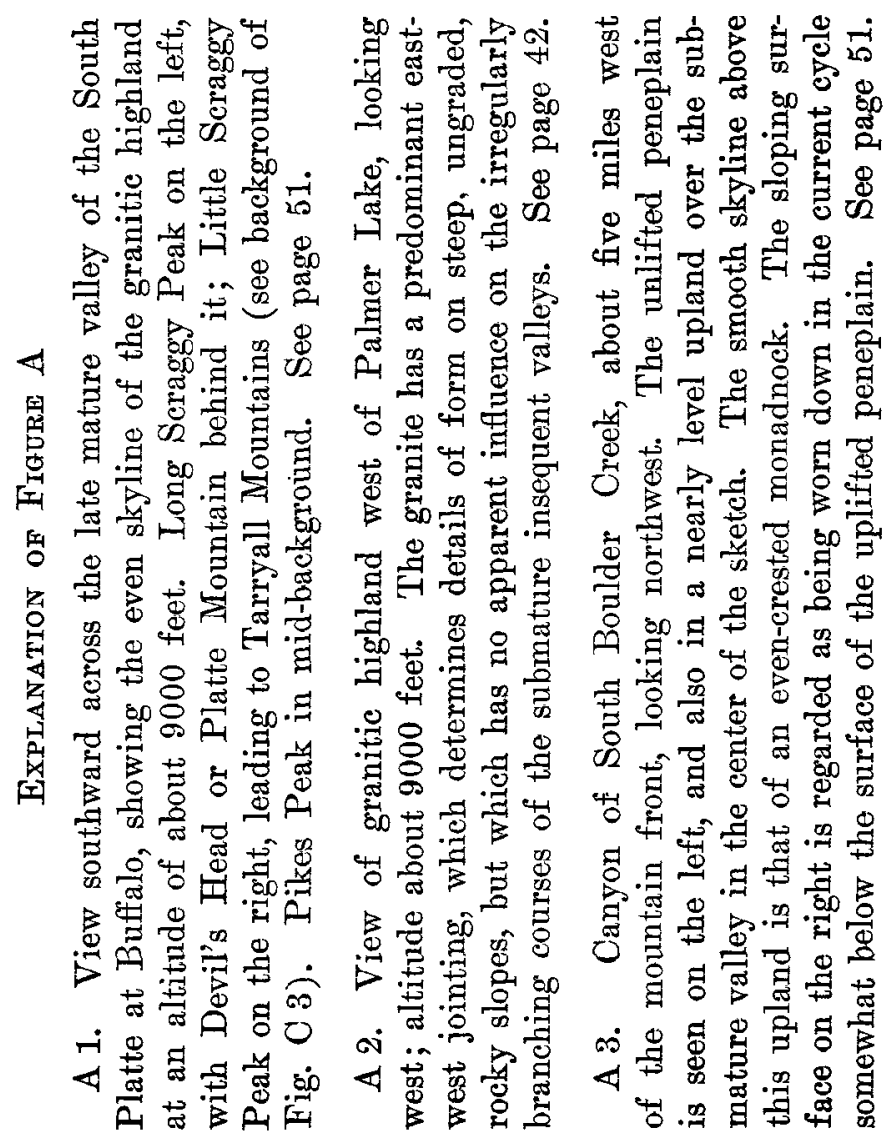




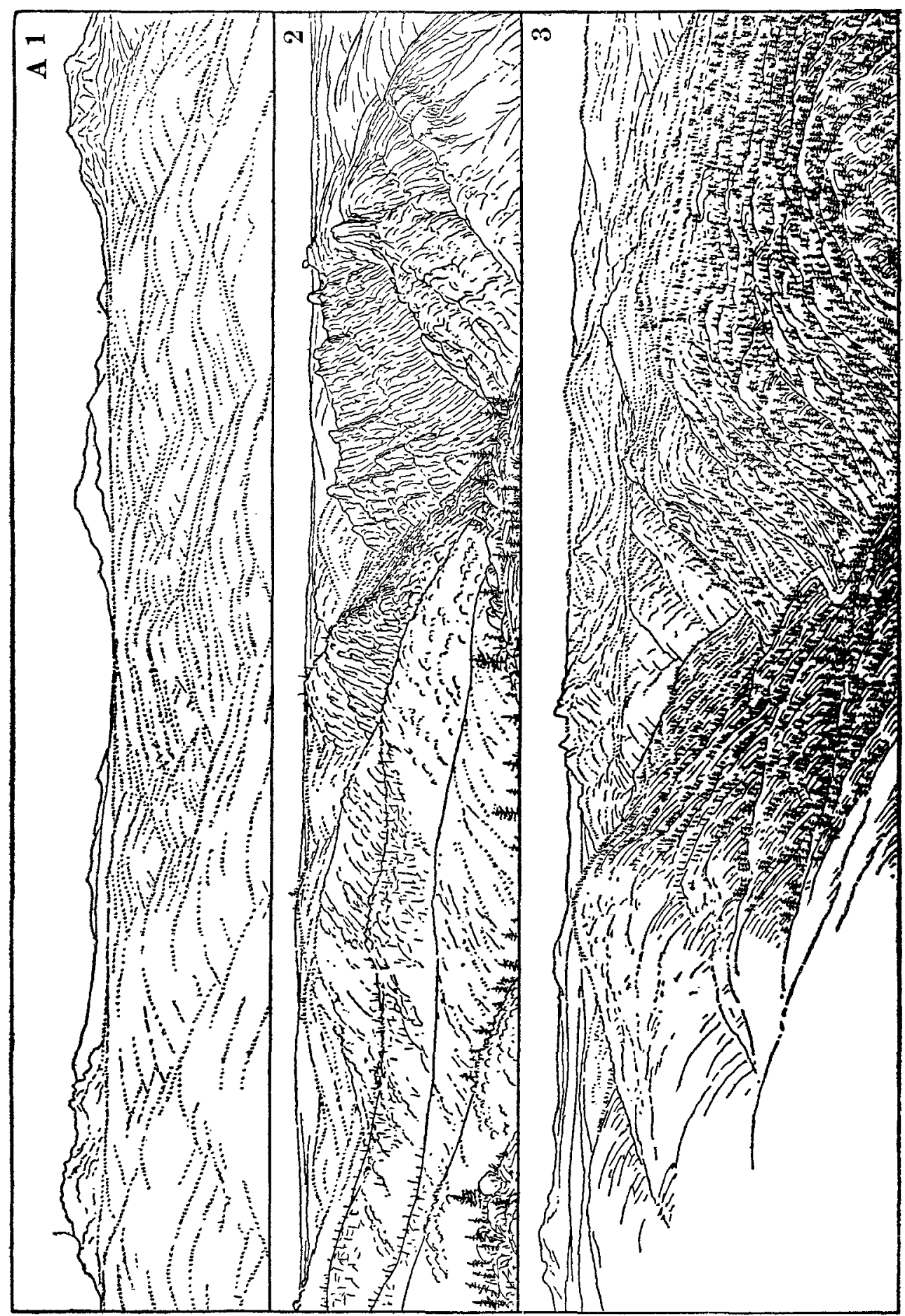




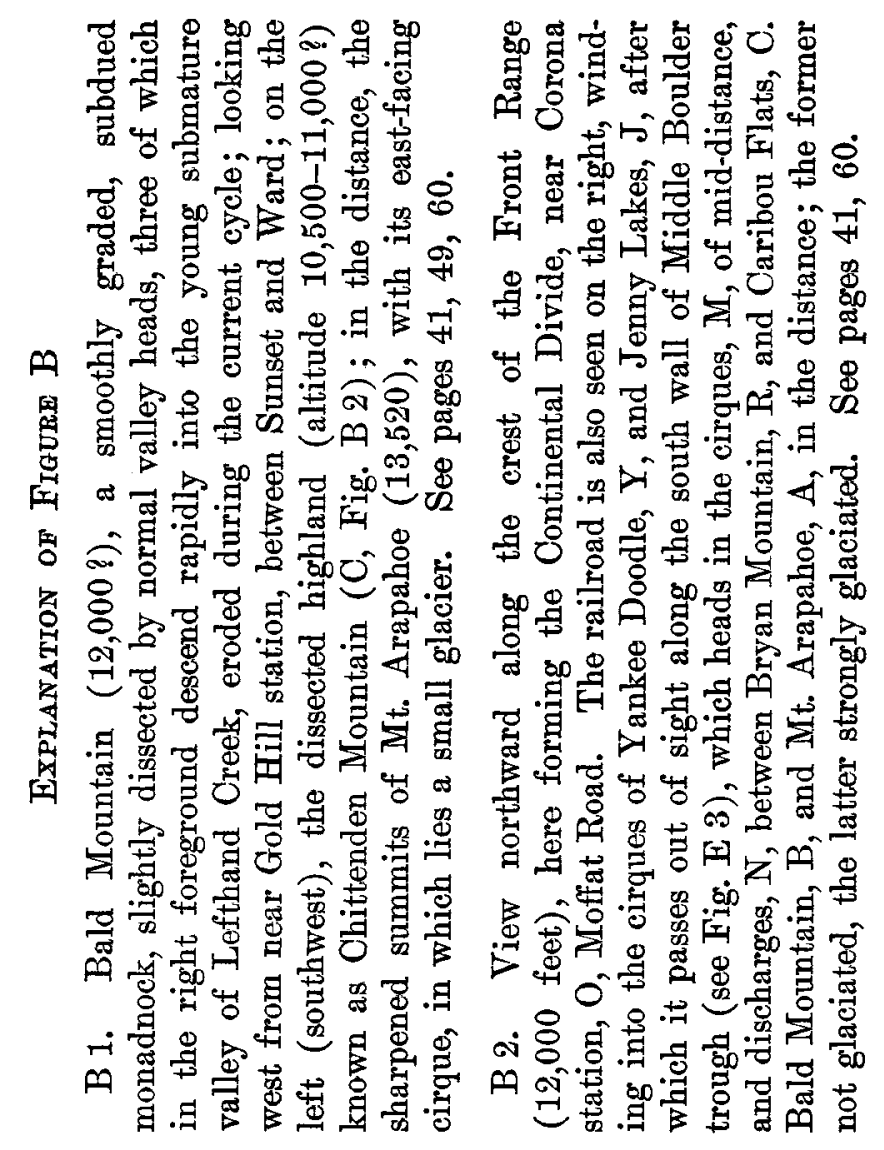




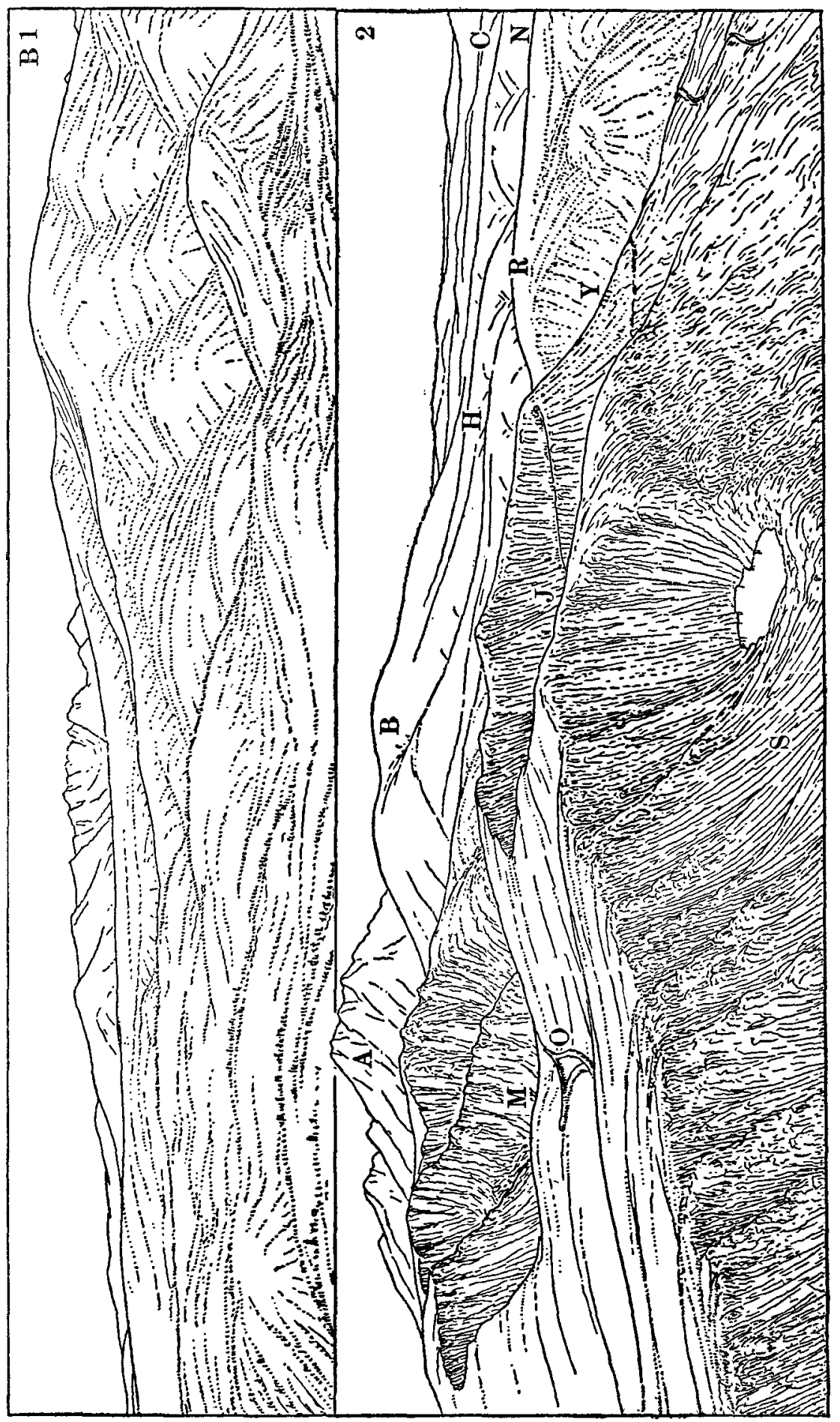


Explanation of Figure C

C1. Sheep Mountain (10,500 feet) surmounting the rolling: highland ( 8,000 feet) south of South Boulder Creek, which flows in a young valley hidden by the foreground ridge; looking southeast. See page 49 .

C 2. Craggy granitic monadnocks surmounting the highland (7,500-8,000 feet) between South and Middle Boulder Creeks; looking northeast. See page 50.

C 3. The gravel-covered highland (10,000 feet) of the South Platte district; Tarryall Range in the distance, looking northwest. See pages 43,50 .

C 4. The same highland (10,000 feet), looking northeast. The farthest sky line shows the district sketched in Fig. A 2; it is separated from the middle distance by Manitou Park, a northwestsoutheast valley excavated on a down-faulted strip of Plains strata. See page 43.

C 5. Pikes Peak (14,108 feet) surmounting the gravel-covered highland, as seen from near Divide station, Colorado Midland RR., looking southeast. See pages 43, 50.

C 6. The north side of South Boulder glacier trough, here called Boulder Park, as seen from Tolland station, Moffat R.R. The railroad follows up the flat aggraded floor $(8,800-9,000$ feet) of the trough from east to west (right to left); then turns back, ascending the trough side in zigzags, and passing on to the cirques, shown in Fig. A 2. Morainic ridges clinging to the side of the trough are indicated between the first and second turns of the railroad, as here shown; and also in an embankment that shuts in a side valley, farther on the right. See page 62. 


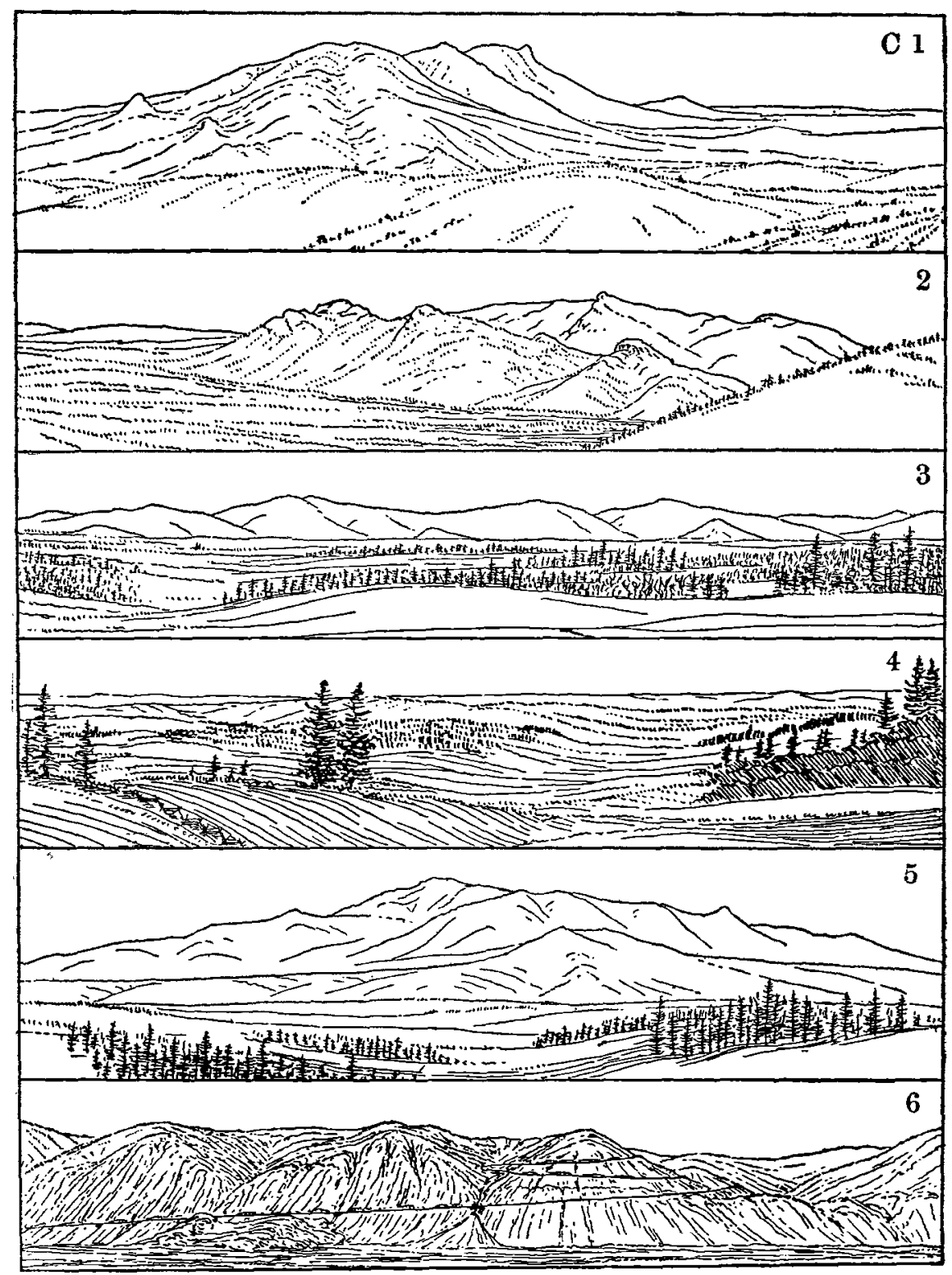




\section{Explanation of Figure D}

D 1. Looking eastward, down the normal early-mature valley of Fourmile Creek. The highland level is not seen, because of monadnocks on the valley border : on the right are Sugarloaf and Bald Mountain (the latter, partly shown, is not the same as Bald Mountain of Figs. B 1 and 2.) The sky line of the plains is in the distance. A narrow gauge line ascends this valley from Boulder to Sunset (hidden behind foreground spur) : there the line divides; one branch turns back on the south side of the valley, rounds Bald Mountain and descends to Eldora in the trough of Middle Boulder trough, Fig. E 3, or below N, Fig. B 2; the other turns back on the north side of the valley, passes, northwestward over the highland and reaches the town of Ward, near the northeastern base of Bald Mountain, Fig. B 1. Both of these towns are in the tungsten mining district. See page 51.

D 2. A small cirque high on the north side of the west branch of Clear Creek trough, Georgetown district, as seen from Mt. MeClelland. See page 63 .

D 3. The unsymmetrical northern spur of Mt. McClelland, with a normally graded slope on the east and a steep glacially undercut slope on the west. See page 63.

D 4. A glacially dissected dome, otherwise of normally subdued form, in the northern part of the Sawatch Range, between two branches of North Fork of Lake Fork, looking north. The cirques were occupied by glaciers 5 and 6 of Capps' map. See page 56 .

D 5. Another example of the same kind in the same locality, a little farther north, between North Fork of Lake Fork, and a south branch of Homestake Creek looking north. The cirques were occupied by glaciers 7 and 11 of Capps' map. See page 56 . 


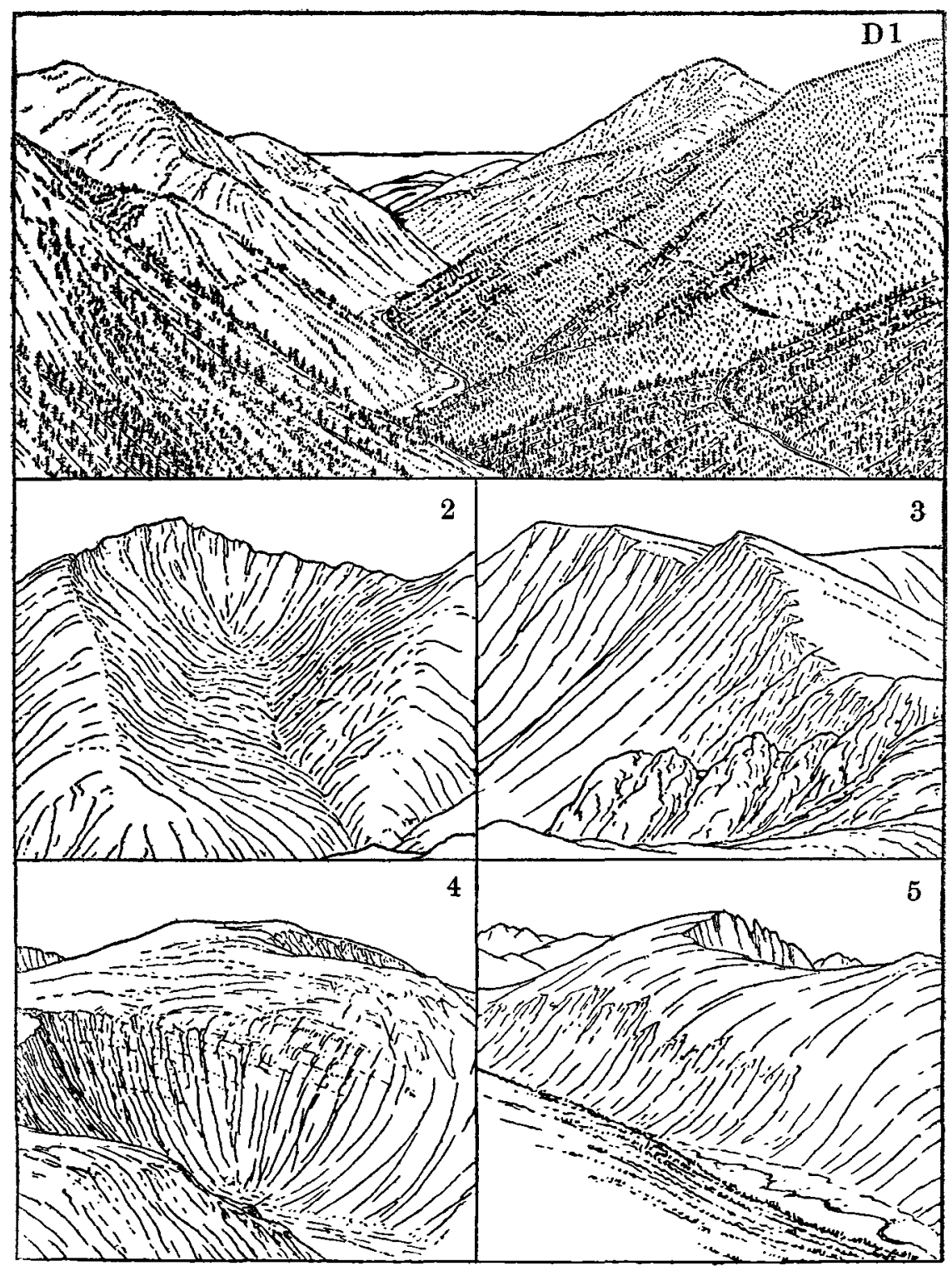




\section{Explanation of Figure E}

E 1. Grays (14,341 feet, on left) and Torreys Peaks (14,336 feet, on right), with waste-covered cirque walls and floors, looking west. See page 63.

E 2. James Peak (13,283 feet), as seen looking south from crest of Front Range, near Corona station, Moffat Road (Fig. B 2). Cirques of head branches of South Boulder Creek in foreground and mid-distance; cirque of Mammoth Gulch (branch of South Boulder Creek) on the east of the peak; and of Jim Creek, flowing to the Grand-Colorado system, on the west. See page 60 .

E 3. View looking eastward from top of cirque wall, over M, Fig. B 2, down the maturely overdeepened and widened trough of Middle Boulder Creek, showing its catenary, or round-bottomed-V cross-section. Eldora lies in the farther part of the trough floor. The Moffat Road is seen near the top of the trough wall on the right. Bald Mountain and Sugarloaf (see Fig. D 1) rise over sloping highlands in center of sketch; the ocean-like sky line of the plains is seen in the far distance. See page 61 . 


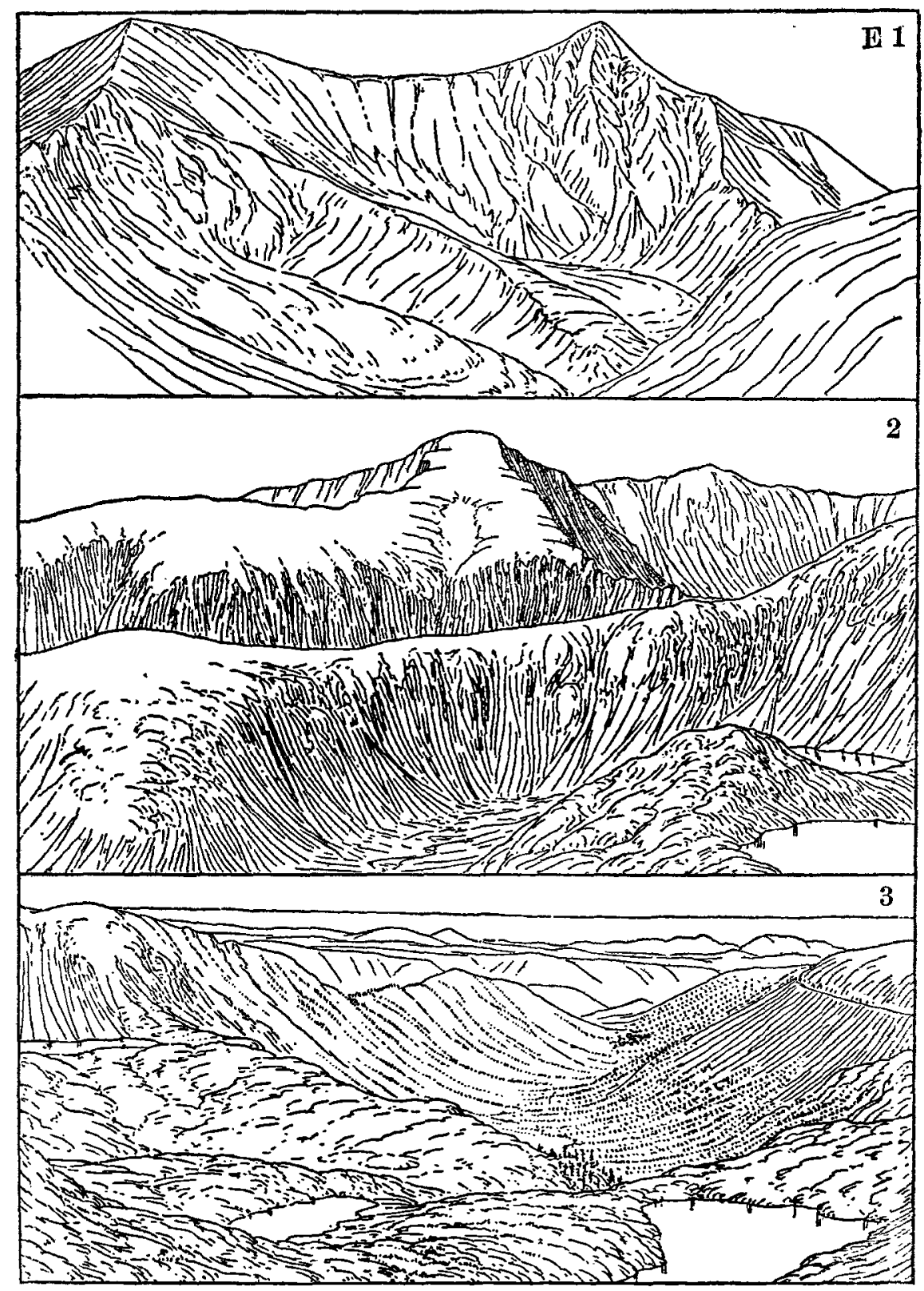

